\title{
CONTESTED JAVANESENESS IN SOCIOCULTURAL DOCUMENTARIES OF THE POST-NEW ORDER INDONESIA
}

\author{
Gerardus Majella Adhyanggono \\ Soegijapranata Catholic University \\ adhy@unika.ac.id
}

\begin{abstract}
This article fleshes out how two Indonesian sociocultural-themed documentary films of the post-New Order era articulate the counter-imaginaries of Javaneseness. They are Jamu (Javanese Traditional Medicine) and Kulo Ndiko Sami (We are Brothers). The emergence of bringing the issue of Javaneseness to light has its cause on its complex politicization in the New Order regime. Javaneseness was ideologically manipulated as the hegemonic narrative of the state to construct an image of Indonesian society. Javaneseness incorporated by the regime was of a desired aristocratic model in combination with other non-Javanese worldviews. This desired strand of imagining was then politically used to simplify the whole gamut of Javanese cultures and marginalize other ethnic cultures. With the collapse of the New Order, sociocultural activists and filmmakers of the grassroots regarded the burgeoning of independent documentary filmmaking as momentum to utilize documentary film as a medium to project alternative interpretations of Javaneseness. The article proposes a symptomatic reading of the examined films by looking at their aesthetics and ideological aspects framed and situated within the oppositional views of the imagined community by Benedict Anderson and Partha Chatterjee. By drawing on the films' aesthetics and ideologies that articulate Javaneseness, this article aims to show two points. First, the counter-imaginaries of the New Order's Javaneseness are projected through the documentaries and such projections prove to be dynamic. Second, inclusive views on how to represent ethnicities in contemporary Indonesia need promulgating.
\end{abstract}

\section{Keywords}

hegemony, counter-imaginary, interpretation, narrative, representation 


\section{About the Author}

Gerardus Majella Adhyanggono holds a PhD in Film Studies from Lancaster University, UK. His research interests mainly reside in the intersections of film, culture, and literature with emphases on cultural representation, identity, and symbolism.

He is a faculty member of the English Department, Faculty of Language and Arts, Soegijapranata Catholic University (SCU), Semarang, Indonesia.

Gerardus is a member of the Indonesian Film Scholars (KAFEIN) and also a former member of Java Institute and Asian University Digital Resource Network (AUDRN) for Local Knowledge in Indonesia.

He has published articles in some accredited journals of Indonesia, and presented papers at international seminars and workshops, such that of the Workshop on Indonesian Cinema at SOAS, University of London, UK.

He has conducted several research projects on documentary films and is currently working on $A$ Structural and Cultural Examination of the Archaeological Films at the Institute of Archaeology, Yogyakarta. 


\section{INTRODUCTION}

Jamu (Javanese Traditional Medicine, 2002) and Kulo Ndiko Sami (We are Brothers, 2005) are sound examples of how filmmakers of the grassroots "play with" their chosen sociocultural themes in the vibrant conditions and booming documentary films in the early period of the reform era. The documentary films above are the object of analysis in this article for textual and contextual reasons. The films textually express the filmmakers' interpretations and representations of Javaneseness as ordinary peoples. Erik Barnouw mentions that "In most periods of documentary history, production has been controlled by groups in power" (286). The filmmakers of the examined documentaries are not those in power. Nonprofessional filmmakers, in the sense of the mainstream cinema industry, produce the documentaries. They are not affiliated with government institutions or the main film industries in Indonesia. They are filmmakers who come from different backgrounds but are similar in showing their passion for documentary filmmaking and for using actualities to voice their perspectives. The documentaries also involve ordinary peoples as their social actors who talk about their daily lives and viewpoints related to the topics of the films brought to light by the filmmakers.

A leading female novelist in Indonesia, Ayu Utami, ${ }^{1}$ produced Jamu in 2002 in collaboration with Erick Prasetya. Theme-wise, Jamu is concerned with Javanese traditional herbal medicine. The film revolves around the mythic qualities of traditional medicine intersected with sex practices in Jakarta's urban life. It was first screened at the Schule Sur Dichtung on October 14, 2002, in Vienna, Austria, and gained a tremendous welcome and appreciation from the audience. As Utami revealed in an interview with a Gatra journalist, she mentioned that the film brought to light the intersections and metamorphoses of masochism-eroticism, parody-humor, and power which were symbolically embedded in a cultural artifact, jamu, the Javanese traditional medicine. A month afterward, Jamu was screened at Teater Utan Kayu, Jakarta on November 14, 2002. Thus, this documentary film was designed to be screened and discussed at smaller scales, such as at schools and cultural and public communities alike (GATRA). In 2012, the Indonesian Film Center, part of the Indonesian Film Center Foundation, with the permission of the filmmaker uploaded the film onto their website for public access (IdFilmCenter).

A marginalized sub-Javanese ethnic community, Sedulur Sikep, produced Kulo Ndiko Sami in cooperation with In-Docs ${ }^{2}$ and Ford Foundation ${ }^{3}$ in 2005. The documentary film describes the struggle of Sedulur Sikep (Samin) people to get recognition from the government on their existence culturally, socially, and legally. Sedulur Sikep is part of Javanese society that is distinct from the majority of

Javanese. This documentary film competed and was screened at the Festival Film Dokumenter (FFD) 2005 held on December 13-17, 2005, at Fort Vredenburg in 
Yogyakarta, Indonesia. Although Kulo Ndiko Sami did not win the competition, the film managed to be one of the finalists and received a high appreciation from the judges, the participants, and the audience alike (FFD 15). Afterward, the film was screened in a variety of communities and societies. It was also sold in VCD format for the public (Hartiningsih 12).

Contextually, in the history of Indonesian documentary film, the Indonesian governments from 1945 to 1998, particularly of the New Order regime (1967-1998), were in full control of the documentary production, distribution, and even exhibition (Hanan, "Innovation and Tradition" 107; Hanan, "Observational Documentary" 107; Nugroho and Suwarto 121-122). Following the fall of the New Order regime in May 1998, various social, religious, and cultural movements pervaded Indonesia. Among them was independent filmmaking (Ratna 304; Putri 124-125; Rosalia 4-5). The documentaries in this article embody this spirit of independent filmmaking in the first decade of reform periods (1998-2008). Freedom of expression after the end of the New Order regime in 1998 has enabled documentary films to present sociopolitical and cultural issues more freely than before. With this spirit of freedom, documentary films became a medium to express multiple views on sociopolitical and cultural issues including Javaneseness.

In this article, Javaneseness is seen as a mental picture, an image of being Javanese offered and constructed by the filmmakers in their documentaries. Javaneseness is an imagined creation that is established in the films through manipulating the actualities that evokes a sense of belonging. In this regard, Benedict Anderson's concept of imagined community is significantly relevant in this analysis. He prefaces the concept with a premise that a nation is "an imagined political communityand imagined as both inherently limited and sovereign" (Anderson, Imagined Communities 6) The sphere of communities is not only limited to a nation but also an ethnic group. According to Anderson, Javanese is also an imagined community. Further, he affirms that "In fact, all communities larger than primordial villages of face-to-face contact are imagined" (ibid.). The thesis of Anderson's notion of imagined communities lies in his explanation of why a nation and ethnicity are imagined. He thinks that a nation and ethnicity are imagined because members of either a nation or an ethnic group hardly ever meet, see, and hear most of their fellow members. However, they are mentally projected or represented to exist. The image of their belonging, their attachment to the same nation or ethnic group exists. By 'exist', Anderson suggests the idea that an imagined nation or ethnicity is constructed to produce an abstract of "horizontal comradeship" (Imagined Communities 7). Javaneseness as an imagined community puts one in mind of the attachment to Javanese culture and people. In this paper, Anderson's concept is used particularly to designate two important points. First, it is the contention of an imagined community referring to how the New Order regime precisely had 
already practiced this imagining notion of Anderson's nationalism for progress and modernity before the theory was proposed. ${ }^{4}$ In this context the regime blurred the concepts of Indonesian-ness with Javaneseness. Secondly, it also refers to how the examined documentaries express different constructions and imaginations of Javaneseness than that of the New Order. Yet, these imaginations do not stem from any interest of and intention for progress and modernity. The former orientates the inchoate blend of Indonesian-ness and Javaneseness towards a single imagined community while the latter celebrates diverse understandings and representations of Javanesess.

To expose the different readings of Javaneseness above, this paper also employs Partha Chatterjee's oppositional view on Anderson's imagined community. He claims that Anderson's theory of a nation as an imagined community is weak because it is only limited to and from the context of European colonialism and perspective (Chatterjee, The Nation and Its Fragments: Colonial and Postcolonial Histories 5-6). He further maintains that the movements of anti-colonial nationalism spurred in Asia and Africa at the dawn of the twentieth century brought along with them the nationalist imaginations of the colonized. These nationalist imaginations "are posited not on an identity but rather on a difference with the 'modular' forms the [imagined] national society propagated by the modern West" (Chatterjee, The Nation and Its Fragments 5). The idea of difference here refers to what Chatterjee calls the "inner domain" or the "spiritual domain" of the colonized nationalists which bore marks of cultural identity, and not of the political identity. At the same time, they, like or dislike, had to acknowledge and embrace the "modular" forms of the West (the colonists) through its hegemonic superiority in the "material domain," the area of economy, statecraft, science, and technology, to materialize their struggles (The Nation and Its Fragments 6). In this light, this paper adopts Chatterjee's idea that in fighting against a hegemonically constructed imagined community a la the colonists, the colonized has to be grounded in the inner domain to make a distinction and mark their struggles. In other words, an imagined community projected by the colonized could only be executed through a variety of cultural processes and practices. In this article's context, the hegemonic imagined community alludes to the New Order's unitary sense of Javaneseness as for the opponent is the diverse representations of Javaneseness offered in the examined films.

Considering the reasons above, this article argues that the resurgence of documentary filmmaking in the early period of the reform era provides alternative documentary narratives of Javaneseness. These narratives depart from the hegemonic documentary narratives of the state as was once exercised during the New Order regime. In other words, there is no single hegemonic narrative of truth in the context of the documentary films of this period. The stories 
of the documentary films are subjective and experimental, including in their representations of Javaneseness. Such cultural representations express cinematic and cultural attempts to rearticulate Javanese cultural identity in documentary films. This writing explores how cultural practices and expressions deeply rooted in Javanese traditional values and beliefs depicted in the films imply a message of dynamic interpretation of Javaneseness.

From the context of Indonesian documentary films, this article fills a space that is rarely visited by many film scholars, about representing and reimagining Javaneseness. Indeed, expressions and issues of Javanese culture have long been examined, particularly on their aesthetics and ideological aspects in Indonesian fiction films. Some foreign and Indonesian scholars have also studied them (see Heider; Imanjaya; Hanan, "Innovation and Tradition"; Nugroho and Suwarto; Heryanto, Identitas Dan Kenikmatan). Nevertheless, the representation of Javaneseness still seems to be an esoteric subject to explore in the convergence of documentary films and cultural studies.

This article is divided into four main sections and a conclusion. Section one deals with the historic development of documentary film, as both a genre and a device for political propaganda, in Indonesia. This part provides a description of the function and position of documentary film in the country. Section two concerns the New Order's unitary sense of Javaneseness. This part provides the political, social, and cultural explanation of how the New Order regime manipulated Javanese culture, in this case, court culture, aimed to envisage Indonesian-ness in a process of modern Indonesian nation-building. Section three describes the forms and styles of Jamu and Kulo Ndiko Sami. This explanation is significant to provide an essential understanding of the films' aesthetic values. Section four deals with how the examined films challenge the New Order's unitary sense of Javaneseness and articulate their alternative images. The article ends with a summation of how dissonant representation of Javaneseness in the examined films is a form of contestation to the ever-prevailing hegemonic imagination of this cultural ideologue $a$ la the New Order.

\section{DOCUMENTARY FILM AS A GENRE AND DEVICE FOR POLITICAL PROPAGANDA IN INDONESIA}

Documentary films were regarded as a propagandistic instrument of the ruling governments in the context of Indonesia. This is evident in how documentary films were used by these governments during the Dutch State colonial era (18201942), ${ }^{5}$ the Japanese administration time (1942-1945), the Old Order era (Sukarno, 
1945-1967), and the New Order period (Suharto, 1967-1998). Across these periods, documentary films were solely used to deliver the regimes' voice, perspective, and justification (Hanan, "Observational Documentary" 106-107). During the Dutch State colonial and the Japanese administration periods, the governments intentionally made use of documentary films to propagate their interests although there were a distinct style and approach between the two.

The Dutch documentary films such as Moeder Dao (Monnikendam), De Merapi Dreight (Balink), and Het Land van de Overkaant (Franken) were, as Sen explains in her book Indonesian Cinema: Framing the New Order, ethnographic, exotic, and social. For example, Moeder Dao, de schildpadgelijkende, or Mother Dao, the Turtlelike is a 90-minute black-and-white documentary film by Monnikendam, a Dutch documentarist. It tells about how the Dutch managed Nusantara in the period 1912-1933 as a colonial business enterprise. The footage shot without sound shows the exploitation of natural resources by the Dutch. It portrays forests burning, land clearing, oil and gas mining, as well as road and railroad constructions. The propagandistic purpose of the film articulates the colonial attitude at that time where the Europeans were the superior while the indigenous were the "backward peoples." In most of the footage, the Dutch overseers are always described as the ones who instructed the natives to do the labor for them. The Dutch were represented in white tropical garb standing by commandingly with their walking sticks and cigars (Monnikendam).

On the contrary, the Japanese films such as Nihon Eiga Sha's Celebration of the Emperor's Birthday and the Re-Opening of the Medical School for the Natives, Volunteer for the Army, Berdjoang (Hope of South), and Call for Romusha were militaristic and imperialistic (YIDFF Organizing Committee). For instance, Celebration of the Emperor's Birthday in the Berita Film di Djawa No. 2 is a newsreel produced by Nihon Eiga Sha Djawa, a filmmaking unit in the Japanese Imperial Army. It tells about the celebration of the Japanese Emperor, Tentjo-Setsoe Hirohito in 1943. The footage was shot with the sound of a militaristic marching band and trumpet. Voice-over was employed interspersed with intertitles and subtitles in Indonesian and Japanese. The voice-over was also in Indonesian and Japanese languages. This black-and-white footage depicts various places where the Japanese Imperial Army was stationed. It shows a scene of the Japanese Imperial Palace in Tokyo where imperial soldiers and the Japanese masses paid homage to the emperor through a Japanese-style deep bow (Nihon Eiga Sha, Celebration of the Emperor's Birthday).

During the era of Sukarno (1945-1967), the regime mainly produced newsreels aimed to record state affairs, national events, and the president's powerful oratories. As a result, they were utilized as an instrument to boost the personality cult of 
the president. Sukarno's political rhetoric always brought out issues and spirits of nationalism, anti-imperialism, and anti-neocolonialism that captivated the masses (Anderson, "Bung Karno" 6). Allured by his charisma, the mass media was used to record and capture the president's speech. This Old Order regime treated the mass media as a tool of the revolution wherein Sukarno was the supreme leader of the Indonesian revolution.

Another instance of documentary film as government propaganda is Gelora (Independent Enthusiasm, Komite Nasional) . This black-and-white reel shows Sukarno's speech at Gambir or Ikada Square, Jakarta, on 19 September 1945. The film employs a "voice of god" narration and intertitles in Indonesian and English. The newsreel depicts Sukarno's oration to the masses who hail him exuberantly. In his speech, Sukarno encouraged the masses to be strong and to have faith in him to secure Indonesian independence. The propaganda of this film speaks of Indonesian freedom from the Dutch and the Japanese that had been proclaimed on 17 August 1945 by Sukarno-Hatta (Komite Nasional n. p.).

When the New Order regime (1967-1998) replaced the Old Order (1945-1967), the New Order banned all records relating to Sukarno from being published and aired (Sen and Hill 84-85). In the Suharto era, the New Order manipulated documentary films as a propagandistic instrument to legitimize power. Most of the government programs were developmental ones and executed in authoritarian ways. Nearly all ministries financed the production of their documentary films to support their developmental agendas. A case in point was the program of transmigration, moving people, mostly villagers from Java, Madura, and Bali, to other islands. It was produced by the Department of Transmigration and the Department of Agriculture featuring the ministers themselves as the main characters in the documentary (Hanan, "Observational Documentary" 107). All governmental programs, including documentary films, were exclusively broadcast on TVRI (Televisi Republik Indonesia), the only state television station in the country at that time (Nugroho and Suwarto 134).

Certain features characterized the documentary films of this period. These were the extensive use of authoritative voice-over, an illustrative map to designate the setting, an organic and linear structure, and the absence of subjective and personal narration. These were common in the government type of documentary film celebrating the developmental process. There were also ethnographic documentary films that illustrated tribal societies in isolated regions of the country. The documentaries showed rituals, customs, and arts that gave the impression of underdeveloped peoples to the rest of modern Indonesians. This kind of documentary only seems to repeat what the Dutch colonial's perspective did by using "Western fascination" to disclose their fellow countrymen's lives in distinct 
cultural backgrounds. Meanwhile, another type of documentary film was that of the travelogue aimed to promote the tourism industry. In this kind of documentary film, Indonesia was described as an exotic place with its unrivaled natural beauty and authentic cultures (Mae).

The domination of the New Order government in the production of documentary films in Indonesia gave rise to highly propagandistic and indoctrinating documentary films. As a result, the homogenization of the theme and narrative style of documentary films was inevitable. There were almost no variation and no alternative documentary voice but that of the regime. This situation continued until a non-commercial independent filmmaker, Garin Nugroho, produced a documentary entitled Dongeng Kancil tentang Kemerdekaan (Kancil's Story of Independence). It was about four street children questioning the meaning of freedom and challenging both the society and the government for the fate of their lives in the legendary Malioboro Street of Yogyakarta (Hanan, "The Films of Garin Nugroho" 44; Nugroho and Suwarto 240-241).

Kancil's Story of Independence was considered an attempt to counter the domination of the New Order government which always held the single narrative of "truth" over public issues in Indonesia (Isla 461). The documentary was screened in NHK, a Japanese television station in 1996, and in some Muslim organizations watched by teachers and public officials alike. Indonesian public officials watching the screening were stunned. They considered the documentary as an exaggeration of social reality (Kwok 2). The documentary was then fictionalized as a movie by Nugroho entitled Daun di Atas Bantal (Leaf on a Pillow) (Uhde; Nugroho and Suwarto 241).

With these all in mind, what the general populace in Indonesia understands of a documentary is only associated with political, informational, and propagandistic films as stated by Garin (Hanan, "Observational Documentary" 107). Hanan further underlines the cognizance of the New Order regime to use the rhetorical power of documentary films politically (Sen and Hill 147; Hanan, "Innovation and Tradition" 113; Hanan, "Observational Documentary" 107). As a result, the general public in Indonesia skeptically perceives documentary films as being propagandistic and boring (Irawanto).

Following the fall of the New Order regime in 1998, four characteristics feature the dynamic condition and burgeoning production of documentary films in the first decade of the Reformasi era. First, the cinematographers had more freedom to portray various subject matters, including themes repressed during the New Order regime, such as sex, homosexuality, the irony of development, social injustice, poverty, and provocative issues concerning inter-ethnic and inter-faith 
relationships (Nugroho and Suwarto 299, 315, 323, 325-326; Heeren 108-109). Second, the emergence of documentary and independent filmmaking based around universities, cinema clubs, film festivals, and public spaces was thriving (Hanan, "Innovation and Tradition" 121; Nugroho and Suwarto 297-298; Arifianto and Junaedi 81). The pervading view at that time was "making your own film." It was almost like a creed to produce independent documentary films on various themes boundlessly (Ratna 304). The third factor was the advancement and popular use of the digital camera, which was fairly affordable. Digital camera, video, and computer editing have enabled amateur filmmakers to shift from expensive celluloid film productions to digital ones (Nugroho and Suwarto 295, 298; Arifianto and Junaedi 8o). The last factor was the active involvement of women in producing films of various genres, which became more recognizable (Hughes-Freeland 423; Michalik $380)$.

The first decade of the Reformasi era also witnessed the rise of documentary filmmaking by the grassroots. There have been some essays written on the subject of filmmaking activism in the grassroots in the context of post-New Order Indonesia. Yet, none of them deals with Javaneseness as the writer does. Lulu Ratna's essay, for example, focuses on the movement of short filmmaking in the post-1998 era. In her article, "Indonesian short films after Reformasi 1998," Ratna states that the Indonesian short-film movement is burgeoning after the sociopolitical reform in 1998. However, she further explains that the campaign is still struggling to exist due to its central and non-permanent contribution of the film communities supporting it (Ratna 307).

This situation occurs as the Indonesian government support and funding could only reach acknowledged and legalized film events, such as the FFI (Indonesian Film Festival) and national student film competition. Film communities in Indonesia are established as underground communities by nature. Thus, the issue of their legality matters before the government. There are still special requirements and permits for the communities to be able to produce and screen their films legally. Although the reform era seems to make everyone able to create movies and make film festivals, without the legal status from the government, a clear way to get government funding is hard to achieve. The fluid nature of film communities where their members can quickly come and go give a disadvantage impact on their model of crowdfunding system to survive (Ratna 306-307). In this situation, the funding aid offered by foreign sponsors is a promising source to make film communities survive and to hold film workshops, screenings, and even festivals (Karnanta 7-8).

In this early reform era, the circulation of Indonesian documentary films along with independent and short films made use of three channels outside the mainstream cinema theatres. These channels are the alternative sites of screening 
and distribution. They are film festivals, on-campus (at classes and seminar rooms), and off-campus screenings (at cultural centers and even shopping centers). Thus, amateur and idealist filmmakers tended to use these three channels to screen their works to the public (Arifianto and Junaedi 8o-81). This situation occurred because of certain factors. Indonesian documentary and short films could not be screened in cinema theaters for a film conglomerate that had monopolized distributions and screenings of films in its network since the 1990 os rejected them. This conglomerate is known as 21 Cinema (Jaringan 21). This company mainly screened imported films of Hollywood and Hong Kong during those times (Sen and Hill 139, 151; Nugroho and Suwarto 226-227).

The resurgence of documentary and independent filmmaking activism also came along with the enthusiasm of women in film production. Hughes-Freeland (2011) highlights the importance of women as film directors, producers, trainers, publicists, and distributors to express themselves and speak for themselves. One of the methods is by using documentary films they produce to express private and social problems they face. She suggests that the involvement and creativity of women give rise to "a more diverse and heterogeneous film culture" in the context of Indonesia (Hughes-Freeland 417).

\section{THE NEW ORDER'S UNITARY SENSE OF JAVANESENESS AND INDONESIAN NATIONAL IDENTITY}

Javaneseness significantly matters in this interrogation because, in the political history of Indonesia, the authoritarian New Order regime developed a hegemonic state culture orientated towards the characteristics of the aristocratic Javanese. The history of the modern Indonesian state is roughly divided into three periods: the Old Order period led by Sukarno's regime (1945-1967), the New Order period ruled by Suharto's administration (1967-1998), and the Reform period governed by five different presidents (1998 to the present day) owing to the democratic elections. Out of all seven Indonesian presidents, six are Javanese.

The transition of power between these periods did not go smoothly as political upheavals, public demonstration and social movements (people power) always came along with them (Vickers 156-160, 205; Mietzner 1-2, 5). A political rivalry between the Indonesian Communist Party and the Indonesian Army took place during the Old Order period to gain President Sukarno's support. The competition led up to the abductions and the murders of some Army generals and officers in 1965. This tragedy became the main trigger to topple Sukarno's Old Order. Suharto, of Javanese origin and chief of the Army's strategic reserve command, subdued 
the attempt of a coup by the Indonesian Communist Party on September 30, 1965. This incident preceded the rise of Suharto's New Order to replace Sukarno's regime through a transfer of power by the mandate of the People's Consultative Assembly (Vatikiotis 2; Vickers 160; Hunter 62).

Having overthrown the Old Order regime, the New Order highly prioritized economic development to boost Indonesian modernity. This policy neglected other aspects of people's lives, such as freedom of expression and human rights, for over thirty years. The regime developed a state culture where unity was overemphasized while diversity was domesticated. This was solely designed to prevent threats to the regime's economic developmental agenda. In a condition where the state tightly oversaw its citizens through the state apparatus, the New Order regime developed the aristocratic Javaneseness. The combination of policing its citizens and projecting the elitism of Javaneseness induced a negative mentality among most Indonesian civil servants, a fear of superior authority, excessive self-control, and a lack of initiative-seeking (Vatikiotis 109). As a result, personal relationships to get promotion among the civil servants and to approach public officials pervaded the regime's governance. This situation begot chronic corruption, collusion, and nepotism in the bureaucracy of the New Order. In the mid-199os, corruption, collusion, and nepotism were aggravated by the state's foreign debts, the Asian financial crisis in 1997, and the domestic pressures forcing the New Order regime to its demise (Robertson-Snape 600-601; Vatikiotis 204, 219-220).

In the Indonesian reform era, a lot of people readily criticized and despised many things pertinent to the cultural past, especially Javanese cultural practices and beliefs. These cultural expressions were once overtly politicized and manipulated by the New Order regime. Wayang kulit performance was a case in point. Wayang kulit performances carrying traditional Javanese worldviews and values became less popular and were treated with suspicion, particularly in urban areas. The Javanese have a conviction that all existence is united and related in this universe. Existence is managed in a regulated order of the world, a cosmological context (Mulder, "Aliran Kebatinan" 105). Human existence as an individual and part of a society is also included in this order. Human life is inseparable from both spiritual and non-spiritual dimensions. Thus, human life is related to supernatural powers (Mulder, Mysticism, and Everyday Life in Contemporary Java 16-17; Mulder, Mysticism in Java 32).

The Javanese perceive that it is not essential to contradict between the seen and the unseen, the physical, and the supernatural as they are always there and complementary. Keeping the balance of this universal order and within human life experience is significant. Therefore, the Javanese emphasize "inner-tranquillity, harmony, and stability, the acceptance of events as they come and the subordination 
of the individual to society and of society to the universe" (Mulder, "Aliran Kebatinan" 105). With this worldview, a wayang kulit puppeteer traditionally used the show as an educational medium to remind the audience of the importance of keeping balance and harmony in life. Yet, during the New Order period, wayang kulit performance was frequently politicized to deliver the regime's developmental agenda (Basuki 74-75).

In the early period of the Reformasi era, this politicized art form of the New Order regime was in part misleadingly challenged for the regime had positioned Javanese culture as a privilege among cultures of other ethnic groups (Budianta 110). Several reasons paved the way for the challenge. First, some Javanese cultural forms and practices expressing traditional values, such as that of wayang kulit, were associated with the ways the New Order used to propagate the regime's developmental programs (Budianta 116; Basuki 74-75). Second, radical and reformist Islam distanced themselves from such cultural practices and even believed that the traditional methods would stain the true teachings of Islam. This general view of the reformist Islam has been mainly propagated since the revival of Indonesia's Islamic modernist in the 1970 (Howell 701-702; Woodward 55). Third, young urban middle-class generations aligned themselves more with pop culture than with any traditional cultures (Budianta 113; Heryanto, Popular Culture in Indonesia 2o).

In conjunction with these reasons, the Indonesian populace in general associated the New Order's priyayi culture to be the "whole" representation of Javanese culture. Such an association is erroneous. Worse, Javanese culture was blamed for being responsible for aggravating Indonesia's acute problems of corruption, collusion, and nepotism (Robertson-Snape 597). This general accusation is far from being sensible and acceptable as Javanese culture and identity are far more complex than what was believed and practiced by the New Order regime.

This article does not intend to provide a homogeneous understanding of Javaneseness as the idea cannot be fixed into a set of attributes. There are no such definite traits typically Javanese. One's attitudes and personalities may be found across different cultures. Nonetheless, it is still relevant to touch upon some characteristics commonly associated with Javanese people, precisely because the New Order regime confirmed such a stereotype. The Javanese are generally represented as being refined, reserved, socially caring, and spiritual. These characteristics are a fragmental piece of the gamut of Java, Javanese peoples, and their complex values (Suseno 38-45, 50-51, 84-89; Herusatoto 42-43; Endraswara, Memayu Hayuning Bawana 138, 140, 143; Werdiningsih 315-316). Such amiable attributes once became the hegemonic cultural representations of the Indonesian state, run by the authoritarian New Order. The regime believed that it was the "proper" characteristics to represent Java and Indonesia. 
In "The Construction of an Indonesian National Culture: Patterns of Hegemony and Resistance," Keith Foulcher points out that the New Order's Javaneseness designates a mental picture of redefined Javanese aristocrats blended with a modern touch from other non-Javanese concepts. This is meant to construct an ideal society in Indonesia.

There has been a tendency to align "Indonesia" with a redefined priyayi [aristocrat] Java . . . an eclectic combination of aspects of a kebatinan [Javanese mysticism] world view and the Dutch colonial mix of public morality and private self-interest [capitalism], all elaborated against a backdrop of the arts, customs, and etiquette of the courts of Central Java. (303)

The quote suggests that the New Order's Javanese aristocratic model is a synthesis of the Javanese elitist manner (aristocratic) and Javanese mystic worldview in combination with "Western" (Dutch) public morality and capitalism. Similarly, John Pemberton, in On the Subject of Java, describes the notion of Javaneseness a la the New Order regime as a redefined model of Javanese aristocrat, an imagination of Java that is court-centric but modern (307).

The New Order government adopted some elements of Javanese court-based priyayi culture to be the permeating values that characterized the cultural representations of Indonesia. The term priyayi originally stems from "para yayi," which means "younger brothers and sisters (of a king)." In the past, priyayi designated a ruling social group that included the king and his families, nobles, and officials, court-based administrators, and local chiefs. Traditionally, a priyayi was a well-born Javanese holding government office thoroughly versed in the aristocratic culture of the courts. He should be familiar with Javanese classical literature, music, and dance, the wayang kulit (shadow puppet), with the subtleties of philosophy, ethics, and mysticism. He should have mastered proper behavior, refined language, and dress. He was also expected to be skillful in the arts of war (Sutherland 57-58).

The New Order regime projected this priyayi culture by envisioning it as an imagined representation of the Javanese and Indonesian peoples as a whole. They were described as educated peoples with lofty and refined language, civilized and well-mannered attitudes with Dutch colonial public moral standards (domesticating women in a family). The description was further mixed with an economic-orientated logic that justified self-profit seeking (Jones, "Indonesian Cultural Policy" 155). Eventually, priyayi culture is a court culture that is rooted in traditional Javanese beliefs and on the self-conduct of a Javanese leader. A traditional Javanese leader is expected to be trustworthy, to manifest his or her words in reality as the correlation of words and deeds reflects self-integrity. Therefore, the traditional priyayi views 
society, social work, and the self as something integral. This view becomes "the priyayi ethos" (Errington 276).

However, the New Order regime seemed to overlook this ethos when adopting the court culture. The regime stressed the obedience of the ruled to the ruler, or the citizens to the government. Then, this obedience mentality along with the New Order's developmental policy functioned as a cultural discourse to legitimize the Javanese-oriented regime. Two circumstances suggest such a condition: the general perception of the regime's civil servants about President Suharto and the over-politicized wayang kulit performance by the New Order regime. Regarding the public opinion of the New Order regime's civil servants, members of the government apparatus view Suharto as a Javanese king. Although Suharto was a Muslim, he still practiced some Javanese asceticism.

Traditional Javanese belief sees that there is a close relationship between worldly and spiritual power. Javanese rulers are traditionally regarded to have these two powers and to be the intermediary between the divine and the world (Suseno; Endraswara, Falsafah Kepemimpinan Jawa 233-234). Such a reading was manifested in the fear of authority in the context of the New Order. This view seemed to find its justification as Suharto's wife, Mrs. Tien Suharto, claimed to be a descendant of Mangkunegaran house, a Javanese principality in the Surakarta region. His subordinates regarded these all as sound reasoning of the aristocratic Javaneseness that the New Order regime practiced (Pemberton 304-307).

As regards the over-politicized wayang kulit performance by the New Order, this traditional art form had to comply with the New Order regime's cultural policy. The culture was used to support the regime's developmental agenda and political stabilization. Such a plan was manifested in certain strategies. First, the New Order's cultural system made art and cultural performances become a means of communication between the regime and its ordinary citizens. Afterward, such cultural performances had to communicate the regime's developmental slogans and messages. Then, the performances were compelled to avert any political topics and discussion. This was achieved through promulgation of generic and inoffensive stories and messages of development and by applying some technical measurements such as reducing the performance time, using refined and polite Indonesian language, and altering elements considered exposing vivid sexuality to the public (Jones, Culture, Power, and Authoritarianism 138-39).

The combination of the aristocratic Javanese mindset and the cultural policy above became the frame of reference for all regional cultures in Indonesia to develop. This New Order's system was implemented to enhance the regime's cultural grand design. The grand plan was to orientate Indonesian cultural evolution towards 
progress and modernity. Ali Moertopo, one of Suharto's most trusted advisors, reveals this orientation of the New Order's cultural strategy in his book Cultural Strategies.

The New Order must be capable of finishing the huge task that faces it, that is to make Indonesia into a stable subject, a strong subject, by the standards of world development. The New Order must be able to execute cultural tasks that are important, executing cultural borrowing (acculturation) in the passage of world history both now and in the future. This is the cultural nucleus that we must formulate now. This includes thoughts and planning connected to scientific and technological progress, economic development, and the development of social systems ... progress in language and the arts and development connected with religion (Moertopo [1978], in Jones, Culture, Power, and Authoritarianism 122).

The policy above suggests that local cultural expressions in Indonesia had to support the regime's developmental agenda. The New Order regime had the authority to ban any cultural practices and performances insofar as they are not in accord with the regime's cultural policy. The diverse cultures in Indonesia were permitted to thrive based on this policy. The combination of this policy and the mentality of aristocratic Javaneseness shadowed the representations of cultural pluralism in Indonesia for over thirty years. Ethnic cultures at the same time became the vehicle of the New Order's justification to voice developmental agendas and to restrengthen the idea of national identity (Jones, "Indonesian Cultural Policy" 150-51). In this context, the imagined construct of the New Order regime seems to have followed the notion of Anderson's imagined community in that both arise from the interest of establishing a distinct and clear sense of nationalism (national identity). The regime had developed an imagining of the nation's ideal society out of the Western modern conception of a nation through modern education, economic development, and scientific progress (the material domain) (cf. Chatterjee, The Nation and Its Fragments; Chatterjee, "Whose Imagined Community?"; Anderson, Imagined Communities).

Such a cultural construct disguised the New Order regime's main interest of stabilizing and controlling the political condition. Therefore, the ideological language of this regime overvalued unity at the expense of diversity. This view applied to nearly all aspects of public life including cultural representations. Representations of cultural pluralism were still maintained after they were domesticated by the cultural policy aforementioned. Such a method was meant to give the impression that there was harmony between local cultures and state culture, namely Java-centric mentality, progress, and modernity (Jones, Culture, Power, and Authoritarianism 140). 
As previously mentioned, an example was the control of wayang kulit puppeteers by the New Order regime. Suharto's cronies established and sponsored Senawangi and Pepadi, two organizations of wayang kulit puppeteers. Politically, they were designed to domesticate the puppeteers. Culturally, these organizations had a task to promote the wayang kulit style of Surakarta as an essential part of Javanese traditional performing art (Cohen 3).

Another example was the ban on the Genjer-Genjer, a folk song of Banyuwangi, East Java. The song's lyrics were about poverty in the region of Banyuwangi. The words told about a poor woman who earned a living from picking genjer (a flat-tasting river plant) and selling it at the market. As the song was used by the Indonesian Communist Party to decry Indonesia's economic inequality and to attract the sympathy of the poor, the New Order regime banned it. The song was viewed as a threat to the state (Parlindungan 237-39).

Some scholars point out that the New Order's version of priyayi culture is very much a simplification of Javanese culture and identity. Javaneseness cannot be summed up by priyayi culture nor by court-based culture alone. There are various Javanese cultures other than court-based ones (Hatley et al.; Laksono 76-79, 85; Pemberton 200, 292). For example, Hatley mentions that both social and geographic factors constitute the diversity of Java. While the court culture is considered a refined (alus) and reserved one, those more distant from the palaces are stereotyped as being coarse (kasar). Other cultural practices away from the heartland courts are as culturally valid as those of the courts (Hatley et al. 1).

Multiple expressions within Javanese culture are evident. Various traditions and rituals speak about them as in the case of the tradition and ritual in the district of Bagelen, Purworejo, in Central Java. In this district, some villages develop their local histories, myths, legends, and village cleansing (bersih desa) traditions irrespective of the past political influence of the court of Yogyakarta (Laksono 76). Pemberton further confirms such phenomena as he demonstrates the various customs of village cleansing in different regions of Wilagen, Bayat, and Pedan. However, such diversity had occurred only in the period before the New Order's pro-development cultural policy and a unitary sense of Javaneseness was imposed. As a result, messages of harmony, security, well-being, and one-ness were heavily promoted (Pemberton 239-242). 


\section{FORMS AND STYLES OF JAMU AND KULO NDIKO SAMI}

\section{Form and Style of Jamu}

Jamu is an essay-formatted documentary produced in 2002 in Jakarta, Indonesia. The film's duration is 25 minutes. It is in English and Indonesian languages with English subtitles. Jamu was filmed using a standard digital video (DV) format. The film was produced and directed by Utami and Erik Prasetya, and the latter was also the cinematographer. The documentary shows a personal city-tour of the filmmaker to unveil social reality and beliefs about the practice of consuming jamu and sex practices in Jakarta, the capital city of Indonesia. The film takes jamu, Javanese traditional medicine, as its subject matter. The word jamu itself is of Javanese origin and culture (Beers 11; Soedarsono and Roemantyo 1).

The leading actor here is Utami (the narrator). Other supporting actors are Sariyem (a traditional jamu vendor), Suyoto (a street vendor), Pandu Riyono (a family health consultant), Jalu Patidina (a male consumer of jamu concocted from a cobra's liver), and Prasetya (the cinematographer). Prasetya is seen before the camera in the last scene. In this scene, Prasetya performs as Utami's spouse in their intimate dramatization.

The setting of the film takes place in several areas in Jakarta. These are the areas of the National Monument (Monas) and the State Palace, a jamu stall in Jakarta's urban district, some places of Jakarta's ex-red-light district Kramat Tunggak, a café and a jamu stall in the Old Town Batavia, Jakarta's Chinatown, and a motel bedroom in the central region of Jakarta. A film scene also takes place in the Bogor (a town to the south of Jakarta) Botanical Garden.

Jamu demonstrates the qualities of a first-person essay and testimonial documentary. As a first-person documentary, the film shows Utami's account of what she experiences disclosing the sexual and mythic-oriented motive of consuming jamu. This journey brings her further to expose sexual practices in Jakarta. The dramatic effect of the combination of this participatory, performative, and first-person essay film lies in the gradual self-revelation of the correlation among the public moral view, jamu, and sexual practices.

As to the testimonial quality, Jamu conveys oral witnesses of the actors' personal views and experiences regarding jamu and its aphrodisiac myth. The testimonial quality of the film is depicted in two interview scenes of Jamu. The first of these scenes presents three persons-Sariyem, Suyoto, and Pandu Riyono. In this interview scene, Jamu shows the three giving their testimonies about a myth of "dry vagina." The scene starts with the interview of the narrator with Sariyem in medium 
and close-up shots. Sariyem, depicted as a middle-aged Javanese woman wearing a bandanna, blue scarf, and batik, confesses the importance of jamu for women to maintain their private organs free from excessive dampness. This condition is achieved by regularly drinking jamu.

According to Sariyem, the myth behind this practice is that a man likes to have sexual intercourse with a woman whose private organ is moist or dry rather than excessively wet. Here, Sariyem asserts, "Of course men prefer 'dry vagina.' They don't like it if it is too wet." Afterward, the film shows Suyoto in a close-up shot, confirming Sariyem's statement, "Well, dry is nicer." Then, the scene presents Pandu Riyono in medium and close-up shots. He challenges the myth, "About dry sex; it is only men who believe that a 'dry vagina' gives an extraordinary sensation." In the shot that follows, Suyoto in close-up, with his serious facial expression reassures the narrator that the myth is true, "Dry is so nice, friend. You don't know it!" This scene signifies the intersection of jamu and sex from widespread social perceptions.

The second scene describes the interview of the narrator with a man drinking a cup of jamu concocted from cobra's liver and gin in a jamu stall at the Old Town, Batavia. The scene begins with a medium shot of a man holding a cobra with its head hanging upside down. The man grabs the cobra's head and cuts it off with a blade. He extracts the snake's liver and blood and concocts them with a shot of gin in a small cup. Then, the scene, in medium and close-up shots, presents a male consumer, Jalu Patidina, drinking the concoction. Patidina holds up the container, smiles before the camera, and drinks it in one shot. He argues that drinking this kind of jamu is good for his skin and more importantly his vitality. Afterward, the scene also captures a waitress who confirms Patidina's reasons to the narrator. She said that most male customers drink jamu for skincare and virility. This cobra jamu scene also provides a social perception of jamu and sex.

Jamu, by genre, can be considered a participatory and performative documentary as well. According to Bill Nichols, a participatory quality of a documentary rests on the filmmakers' involvement in shaping what happens in front of the camera. This kind of film shows a reliance on the personal interactions of the filmmakers and their actors. The film uses the speech between the filmmaker and the social actors in interviews. It also demonstrates the filmmakers' manipulation and distortion of confessions and actions. The film also engages with an intense encounter with other social actors and social realities to present a perspective (Nichols 210-211).

In this regard, Jamu shows how the narrator, Utami, is involved in interviews with other actors. She even participates in consuming jamu as described in one of the scenes where she comes to a jamu stall. With asynchronous non-diegetic sounds of a traditional Javanese zither chelempung and the "E Jamune" song in 
the background in combination with hand-held camera tracking, the scene shows a jamu stall in a dense residential area of Jakarta. The scene demonstrates Utami and a male actor riding a motorbike. They are looking for a jamu stall. When they enter the booth, the camera captures and zooms in on a favorite jamu brand, Sido Muncul, at the stall's signpost. In this jamu stall scene, the narrator orders a glass of jamu for women. Then, she gets involved in a brief conversation with the vendor as he is making the concoction of jamu.

The vendor: Iya telur bebek [Yes, we use duck egg]

The narrator: Ngga telur Ayam kampung? [Not the egg of a free-range chicken-eating natural diet?]

The vendor: Oh ngga ... [No ...]

Having finished drinking the concoction, she says, "This is called Sari Rapet or the essence of tightness. It strengthens the contraction of the woman's feminine organ." While addressing this statement to the viewers, she puts her left index finger into her right palm, folds it, and tightens it up to indicate the act of penetration and the contraction. The film captures this hand gesture demonstration of the narrator in a close-up shot.

Afterward, the narrator takes another jamu from a pile of jamu products in front of her. She then states: "This is also another kind of traditional product. We call it Tongkat Madura or Madurese Stick. Madura is very famous because of its products and jamu for women ... Direction for use: insert this medicinal herbal into a woman's female part, and let it remain for one or two minutes. Then take it out. It will absorb excess liquid and banish unpleasant odor."

The action at first shows the narrator taking the jamu in a medium shot. Then, as she explains the jamu, the shot shifts to an extreme close-up highlighting the Tongkat Madura in its bright red package, the fingers of the narrator open the box and pull the content out. It is a white cylindrical stick with oval forms at its ends, resembling a phallic shape. This phallic form jamu along with the narrator's explanation highly reaffirms the documentary's engagement with the theme of sexuality. The jamu stall scene illustrates a self-revelation on the part of the film's idea of sexuality. The writer considers that such an interactive scene between the narrator and the jamu stall vendor as well as her manipulative actions indicates the filmmaker's interference and provocative attitude that help express the participatory mode of the film.

Jamu also shows its performative qualities. A performative documentary reveals the filmmakers' point of view dissociated from a more broadly social perception 
(Nichols 210). In this case, the social perception is about the public moral view claimed by the narrator, "We are a moralized society." A performative documentary, as Nichols adds, also shows the filmmaker's direct experiential encounter with the subject matter of the film and the film's social actors (Nichols 211).

In this regard, Jаmu demonstrates these qualities as shown in the jamu stall scene and the fictionalized sex of the motel bedroom scene at the end of the film. Moreover, Jamu also relies on the filmmakers' voices to organize the film. A performative documentary, as Nichols further explains, is also characterized by the use of testimonials, essayistic forms of speech and dialogue. The film underlines its strong personal engagement of the film's subject matter, of what it feels like to get involved with the topic in a particular way (Nichols 211).

The central idea that the filmmaker of Jamu develops is that jamu as a cultural product of the Javanese is heavily imbued with the blend of the public moral claim and sexuality. The moralistic belief is no longer reliable as the tour indicates the opposite. The connection between jamu and sexuality, the film shows, lies in the sexual motives behind the drinking custom of jamu, the myths underlying the tradition, and the notion of jamu's origin. This idea of authenticity deals with a perception that jamu is indeed a cultural legacy whose ingredients, concoctions, and consumption are mostly of Javanese and Indonesian origin. As the convergence of jamu and sex unfolds, the demonstrations of sex practice become further materialized. The documentary argues that such a moralistic claim, "We are a moralized society," needs to be reconsidered or that the free-sex practice just needs to be socially admitted as a fact.

The establishing shot of the documentary begins with the portrayals of some buildings and state symbols, such as the Indonesian State Palace, the national emblem of Garuda, the flag, the National Monument, and some city landmarks. Unlike the narratives of fiction films, those of documentary films rely heavily on the development of the central ideas instead of the development of actions and characters (Bruzzi 49; Bernard 19; Nichols 23; Bordwell and Thompson 355). In Jamu's opening, Utami, the narrator, introduces herself and reveals her intention to bring the viewers to a city-tour in Jakarta. The setting shifts confirm this sense of tour. The story evolves as she brings to light a public belief, a claim about the piety and morality of Indonesian society, "We are a moralized society." The narrator satirically argues that the piety and morality of the Indonesians supersede those in the cities of Bangkok and Amsterdam notorious for their sex tourism. "But, we are not like Bangkok that is famous for the Amsterdam of Asia. We are not like that, you know. We are a moralized society. Our motto is Jakarta Teguh Beriman, or Jakarta-strong in faith." She claims that such a pious and moralistic society is possible as the Indonesians maintain their physical and religious lives well. Then, 
she introduces jamu as something that is commonly consumed by the public and contributory to the well-being of the Indonesians.

As consuming jamu by the public is common, the narrator begins to expose the primary motive behind the practice. In so doing, she conducts some interviews and field observations and tries to contrast the moralistic claim above with the social realities. Jamu shows that the main reason for the public practice for consuming jamu is for virility and vitality. This motive applies to both men and women. From revealing this motive, the narrator develops the story into exposing the ex-prostitution area of Kramat Tunggak and the nightlife of China Town, which is associated with sex businesses. The film, then, starts blending jamu, vitality and virility, and sex practices. The film demonstrates that jamu is also served in the massage parlors and nightclubs, indicating the coexistence of jamu and practices of prostitution associated with those places.

Concerning the film's motif, to illustrate that the idea of sexuality is essential and recurrently manifested in Jamu, many scenes are associated with it. One of them is the motel bedroom scene. The motel bedroom scene dramatizes the sex between a man and a woman who pretend to be husband and wife. The narrator (Utami) and the cameraman (Prasetya) perform as the husband and the wife in this dramatization. The narrator claims that making love in such a place has been part of urban sex life and trend in the metropolitan city of Jakarta. The documentary suggests that free sex has become a social phenomenon in Jakarta and Indonesia as indicated by the revelation of the narrator in the dramatized scene of the motel bedroom sex.

Jakarta is very crowded. Its population during the day is more than twelve million. Millions of people live in satellite cities. They commute every day, and it takes a long journey, and they might already get tired and exhausted when they get home. To maintain the sexual intimacy between husband and wife, some married couple makes love here, after office hour or during lunch break, like me and my "husband," Erik.

The word "husband" itself suggests an informal expression to show that the speaker is repeating someone else's word that he or she disagrees with. In this respect, the narrator refers to the moral claim, "We are a moralized society" that she challenges.

From the outset of the film, the narrator has questioned the moral claim above. This moral claim and the understanding of sex as "the intimate relationship between husband and wife" mark a general attitude towards sex in the context of Indonesia. Sex is morally and socially justified under a legal relationship, marriage. Therefore, the narrator uses the word "husband" in the quote above to satirize the moralistic view of sex in Indonesia, particularly in Jakarta. The documentary tries 
to deride the moral view by combining it with the cultural practice of drinking jamu, the vitality and virility motive behind it, and the dramatized motel sex. These converged ideas are crammed into jamu, a product of cultural legacy whose name and origin are rooted in Javanese culture and tradition (Beers 11; Soedarsono and Roemantyo 1).

Throughout Jamu, the filmmaker makes use of rhetorical devices, such as the narrator's commentaries, the testimonials, the insertion of stock footage, and the demonstrations of places or items implying sexual connotations, to advance the film's argument. The film's argument derives from the filmmaker's subjective and personal experience to investigate, interpret, and develop jamu. The theme of sexuality, which involves the moralistic claim and the social reality, is ironic as the film's argument begins to be revealed. The introductory scene convincingly displays a moralistic attitude of the narrator whereas the motel bedroom scene expresses a seductive portrayal. This changing representation also shows a shift of the film's tone, from solemnity in the introduction to humor and provocation in the end.

The presence of the narrator is crucial in Jamu. The narrator assumes the function as the explicit and implicit voices of the documentary (Nichols 74-75). The role of the narrator is to help the narrative progress from scene to scene. It is significant as the narrator interweaves the social realities and commentaries of the interviewees to be the evidence. There are two kinds of evidence employed in documentary film: inartistic or non-artificial and artistic or artificial proofs. Inartistic evidence refers to things that tend to be disputable, such as facts, ideas, and beliefs. The artistic evidence designates anything shown out of the filmmaker's invention or creation that may appeal to the emotions of the audience (Nichols 78 ).

Both inartistic and artistic evidence is present in Jamu. They heighten the moralistic claim, "We are a moralized society," and its opposing realities. The narrator counters such a moralistic view with some pieces of evidence. The first inartistic evidence is the social and cultural practice of consuming traditional medicine (jamu) for sexually-related matters, especially in the scene depicting the myth of sex. This scene features three interviewees, a traditional jamu vendor (Sariyem), a street vendor (Suyoto), and a family health consultant (Pandu Riyono). The narrator separately interviews them about the motive of the people drinking jamu. Framed in close-up and medium shots, they tell the narrator that vitality and virility become the main reason why people consume jamu as explained previously.

Such an exploration by the narrator represents a situation wherein a society claiming to be pious and moralistic, the reason for vitality and virility in consuming jamu is still expressed. This description seems to nullify the moralistic view in 
that the documentary presents the ongoing social attitude and cultural practice connected to jamu. This discrepancy suggests that the claim, "We are a moralized society," is only used as a discourse to represent an idealized facet of the society politically. The film makes use of jamu as the cultural entry point to challenge such a moralistic claim.

The second inartistic proof is concerned with the exposure of the ex-red-light district of Kramat Tunggak, which is converted into Jakarta Islamic Center. This scene illustrates a transformation in Kramat Tunggak, a district that was notoriously known as Jakarta's red-light district in the northern vicinity of the capital. The area once housed hundreds of prostitutes strolling up and down the area. The scene shows the narrator explaining the history of Kramat Tunggak, in front of a nearly abandoned theater, Kramat Jaya cinema. When she gives her explanation, the frame also captures some old film posters exhibiting some sexual content. This portrayal seems to give the impression that the sexual materials the posters display echo the past "glory" of Kramat Tunggak. Now, the brothel, pub, and bar have been changed into the Islamic Center of Jakarta since the Indonesian 1998 political reformation. Another symbol of the opposite extreme now replaces the symbol of Jakarta's redlight center. Shots of the construction of huge minarets and a green board on the site reading, "The Islamic Center of Jakarta" in Indonesian and Arabic encapsulate the idea that the transformation is in process. The scene shows a sign of amplifying the claim, "We are a moralistic society."

Another inartistic proof is the representation of the nightlife in Jakarta's Chinatown. This scene in mobile framing initially portrays street stalls selling food and jamu to increase virility and vitality, such as ular (snake), biawak (monitor lizard), and monyet (monkey). Then, the scene captures locales of nightlife entertainment, such as karaoke, nightclubs, bars, discotheques, and massage parlors, which are closely associated with prostitution in the Indonesian context. All of these shots seem to oppose the claim uttered by the narrator at the film's outset, "We are not like Bangkok, the Amsterdam of Asia. We are a moralized society." This scene articulates that in a society claimed to be "moralistic', such a profane facet still exists and has its own life.

As to the artistic evidence, the dramatized scene of the motel bedroom sex illustrates imaginative free sex practice in the metropolitan city of Jakarta. This scene becomes the artistic evidence because it shows the intervention of the filmmakers to represent the social phenomena imaginatively and echoes the challenge to the moralistic claim, "We are a moralized society" The scene implies that the moralistic claim and such an imaginative motel creates a paradox. The sex scene between the imaginary "husband and wife" as described previously suggests that sex has become more liberal in a big city like Jakarta in the context of Indonesia. 


\section{FORM AND STYLE OF KULO NDIKO SAMI}

Kulo Ndiko Sami is a documentary produced in 2005 in Pati, Central Java, Indonesia. The duration of the film is 18 minutes. It is in Indonesian and Javanese languages with English and Indonesian subtitles. Kulo Ndiko Sami was filmed using the standard DV format. The film was co-directed by Gunritno, Mohammad Sobirin, and Rabenir. Dian Herdiany and F. Satriantoro produced it.

Unlike the Jamu, Kulo Ndiko Sami is a documentary with a more explicit political theme. The political topic in this film is not in the sense of vying for power control nor domination. This political theme is in the context of the cultural struggle of the Sikep communities to obtain the government's recognition of their traditional faith. The leading social actor here is Gunritno who functions as the narrator and the witness. The supporting social actors from both Sikep's communities and the local and regional authorities provide their testimonies. The setting of the documentary takes place in several locations: the Sikep village and its farming fields, the district office of Sukolilo, some houses of the Sikep people (Gunritno's, Turlan's, Gunawan's and Kukuh's), the regional registrar office of Pati, and the office of the regional legislature of Pati.

Kulo Ndiko Sami expresses the advocacy and testimonial qualities of a documentary film. An advocacy documentary is a nonfiction film presenting strong evidence and examples of a particular subject matter from a specific perspective (Nichols 149). Kulo Ndiko Sami demonstrates this quality. The film urges that the Sikep is culturally marginalized and treated differently by some government officials. This is the film's specific point of view, the perspective standing for the Sikep communities. The film expresses the identity card problem they face, which becomes the film's subject matter.

Kulo Ndiko Sami is, like Jamu, testimonial. Testimonial documentary is featured with oral witnesses of the social actors to recount their personal experiences (Nichols 151). The testimonies used in the examined films are designed to make the narratives of the films more convincing and real than those without testimonies.

Kulo Ndiko Sami, by genre, can be regarded as an observational documentary as well. The observational quality of Kulo Ndiko Sami resides in the film's capability to capture the actors going about their lives as if the camera was not there for them. Nichols (2010) argues that an observational documentary rests its power on the film's images and their indexical links to synchronous sounds and actions. Thus, there is a sense of continuity matching images, words, and actions of the film's 
shots. As a result, this kind of documentary lets the viewers decide for themselves about what they see and hear (Nichols 211).

The establishing shot of the film captures panoramic shots of paddy fields and the sunrise. Then, an introductory scene appears. It shows morning activities in a Javanese village where both the Sikep and non-Sikep, the majority of the Javanese, live closely. Two Sikep families with family members riding motorbikes to a social event in the village. Then, the scene is interspersed with some shots of other villagers going to the event. The harmonious communal life of the Sikep and other Javanese people is expressed in the event shown. The event host cordially welcomes the Sikep members and other guests. Here, the scene captures Sikep people helping the event-host to prepare a banquet. Then, the scene shows Gunritno, the Sikep, and the narrator, providing his testimony in a close-up shot.

We think that we do not differentiate people. We get along with others well. For example, if another relative is holding an event, we, the Sikep, also come and join the celebration. Thus, we do not treat them differently.

Gunritno is represented as a Sikep man wearing iket (Javanese bandanna) and the Sikep's typical black garment. He persuasively addresses the viewers that the harmonious life of the Sikep and other Javanese is not just a manipulated social conduct for the sake of politeness. Gunritno and the Sikep believe that all human beings are equal and they deserve sincere respect from each other.

The story of Kulo Ndiko Sami sets out with Gunritno explaining why his community accepts being called Samin people by other fellow Javanese. Yet, Samin people call themselves Sedulur Sikep (Sikep brother/sister) or Wong Sikep (Sikep people). Gunritno explains that the word Samin in Javanese ngoko (the first stratum of Javanese language) eventually means "sami" or "podho" (the same or equal). Thus, Sikep people believe that all human beings are equal. Gunritno also tells the history of the Sikep people established by Ki Samin Surontiko who firstly taught rural Javanese peasants some principles of life. The teaching emphasizes a simple life wherein farming and managing household chores are celebrated. About the principles of the life of the Sikep, the film demonstrates how Gunritno claims that Sikep people admit what they do and do what they accept. They also do not differentiate people based on their backgrounds.

As the story unfolds, the testimonies of the Sikep describing the difficulties they encounter to get public service heighten the effect of the government's denial of the Sikep's traditional belief, agama Adam (the religion of Adam). The film shows the complexity, for example, when Sikep people also want to apply for a driving license and electric power installation in their houses. The testimonies of Gunawan, 
Turlan, and Kukuh underscore their adversities. They express that it is practically impossible for them to obtain public services without an identity card. All social safety networks and public services provided by the government are based on the citizens' identity cards. The documentary narrative is developed out of the testimonies of the social actors from both the Sikep and the government.

Besides revealing the adversities of the Sikep, Kulo Ndiko Sami also portrays their daily life. The representation of the daily life of the Sikep shows how Sikep women and girls do their domestic chores, such as sweeping the floor, preparing dishes, and hand-washing kitchen utensils, bathing their children, and feeding them. At the film's end, the documentary shows how the Sikep meet, discuss and find a consensus that they will keep on pleading for their wish granted by the government. This scene does not serve as the resolution of the problem as no resolution is delineated in the film.

Kulo Ndiko Sami is developed on the argument that Sikep people are just like any other ordinary Javanese, and therefore they deserve to be justly treated. With this thesis, the filmmaker aims at revealing the fact of the reluctance of the Indonesian authority, especially at the district and regional levels, to recognize the Sikep communities' traditional religion officially on their identity cards. The film indicates that their act reflects widespread religious discrimination and politicization in the state-citizen relationship. This situation compels Sikep people to "negotiate" with such adversity for the sake of practicality, their practical needs. However, from Sikep's idealism vantage point, the unjust situation does not principally cause Sikep people to abandon their traditional religion for it is their core value and belief. This is the method they identify themselves (Shiraishi 97-102, 113-115; Ba'asyin and Ba'asyin 13-15). Therefore, Kulo Ndiko Sami examines how Sikep people encounter their problem with the local authorities concerning their need to obtain the official recognition of their traditional religion.

Interestingly, the way the filmmakers show their support to the struggle of the Sikep is articulated consistently in the cinematographic technique applied. Whenever the film captures the Sikep as the victim of the situation, the camera always captures them at a low angle or, at the least, eye-level positions. The low-angle shot suggests that Sikep people are victims worth supporting and empowering. The eye-level shot implies that they deserve to be treated equally. These shot-angling techniques are utilized in most of the scenes even when Sikep people are in an argument with the civil servant and the government officials. One scene showing how this angling technique is employed features Gunritno, in a lowangle shot, demanding an explanation from a civil servant of the district office of Sukolilo regarding the exclusion of Gunritno's traditional belief from being stated in his identity card. 
In demonstrating its argument, Kulo Ndiko Sami tries to argue through the voices of the actors from both parties, the Sikep communities, and the government officials. Both of them are in opposite stands. The Sikep people want their religious beliefs to be stated on their identity cards while the officials refuse this demand. Instead, the officials put on a different religion for the Sikep, as what Turlan has experienced. Turlan testifies that based on the experiences dealing with the district office staff, his religious belief has been changed by the district office staff from the religion of Adam to Islam and Buddhism without his consent.

On the other hand, the office head of the Sukolilo district elusively argues that he has no authority to change one's religious belief so long as one's religious faith is accommodated in the five "official" religions acknowledged by the government. This incident suggests a form of manipulation. This technique to meet the opposing arguments proves to be useful in making the voice of the documentary explicitly and implicitly well expressed. As a result, a sympathetic tone towards the Sikep people and an ironic or even agitating tone directed towards the officials pervades the film.

The scene above with the superimposed technique describes the meeting of Gunritno and the head of the Sukolilo district. Gunritno appeals to the official to grant the Sikep's wish, recognizing their religion of Adam on their identity cards. At this district level, the Sikep's struggle fails as the official rejects the appeal. The head of the Sukolilo district recommends Gunritno and the Sikep to channel their aspiration to the regional registrar office of Pati that has higher authority regarding matters of identity cards.

In representing the viewpoint of the Sikep people, the filmmaker rhetorically employs several techniques. Some techniques are expressed via the oral witnesses of the actors. Some methods are demonstrated by the actions of the Sikep to represent their life and their struggle to obtain justice. Another way is through the film's message at the film's end. In the end title, the film manifests its message, "Brothers, do not believe in this little story. You may believe this, but you have to understand it; that is why you need to prove it yourselves." The end title prompts the viewers to think critically about the film. At the same time, the end title also invites the audience to come to the Sikep community and witness what has happened to them. This appears to be a strategy of the filmmaker to highlight the problem and to make the viewers stand for the Sikep. What the Sikep have experienced is not a groundless story of the Sikep but an invitation to an experiential reality of the community. 


\section{CHALLENGING THE NEW ORDER'S UNITARY IDEAL}

\section{Liberal, Sexually Driven, and Secretive Javanese}

In Jamu, Javaneseness is symbolically represented through traditional medicine, a Javanese cultural legacy attributed to some functions: medicine, health care, beauty care, tonic and beverage, body protection, and endurance (Soedarsono and Roemantyo 1). With such functions, jamu, as shown in the film, is composed of ingredients from herbal, mineral, and some animal products (Elfahmi et al. 52). Then, the representation of jamu in the documentary is allied with the theme of sexuality and the public moral view, "We are a moralized society." The imagination of Javaneseness is materialized out of the convergence of sexuality and this public moral belief.

With such a combination, the representation of Javaneseness in Jamu centers on an image of the Javanese who are liberal, sexually driven, and secretive. Anderson's model of a single imagined community out of the interest of nationalism for progress and modernity, which the New Order also believed, does not work in this film. Why so? The representation of Javaneseness above strongly expresses the film's denial of the New Order's unitary imagined community for progress and modernity that is ethical, educated, and capitalistic. Demonstrating the qualities of being liberal, sexually driven, and secretive is also an attempt to view Javaneseness from a different angle. It is a subjective angle that is provocative, speculative, and perhaps undesirable by many Javanese themselves. Yet, Jamu presents it as a counter-imaginary of the "shared" imaginary model of a community a la Anderson and the New Order. By representing such qualities, the self-imagining aristocratic Javaneseness of the regime and its refined sexual morality are no longer believed to be the hegemonic view of the state in post-New Order Indonesia. At this point, jamu has functioned as the entry point that articulates the opposing stance of the public moral view using social realities, which are captured and fabricated in the film.

The liberal quality of Jamu's Javaneseness is articulated in the scene of the motel bedroom sex. The scene portraying the fictionalized sex between the filmmakers indicates a phenomenon of a more liberal man-woman relationship than in the times of the New Order. This liberal relation includes free-sex (pre- and extramarital sex) practices in the Post-New Order urban life in many big cities in Indonesia (Francoeur and Noonan 538). The scene signifies the overturning of the New Order's orientation of sexual morality. This portrayal communicates a challenge to the view of the public moral view and values of sexuality, especially Javanese marriage values. This articulation speaks of what Chatterjee calls "the inner or spiritual domain" (The Nation and Its Fragments; “Whose Imagined Community?”) 
of the Javanese. Why should they be related to the Javanese culture? Jamu has already framed the film's theme and cultural background within the Java-centric culture as expressed in the scenes preluding the dramatized motel bedroom sex.

Two scenes lay out the film's reference to sexuality and marriage values in the context of Javanese culture before the dramatized sex scene. They are the energy-boosting drink, Kuku Bima TL scene, and the Loro Blonyo statuettes scene. The Kuku Bima TL scene presents the narrator rhetorically stating that sex is understood as an intimate relationship between husband and wife. The Kuku Bima $T L$ scene captures this narrator's address to the viewers, and the figure of a Javanese mythological character, Bima, as the jamu's brand image of manhood. Loro Blonyo scene reemphasizes the notion of sex as the husband and wife's consummation. The scene portrays the narrator holding a pair of Loro Blonyo statuettes and jocularly playing them on her lap while making the explanation to the viewers. This scene suggests that the Javanese cultural setting is indeed employed in this documentary.

With such scenes preluding the motel bedroom sex, the dramatized sex of the motel bedroom scene expresses the liberal, sexually driven, and secretive facets of an imagined Javanese. Such a representation articulates a deviation from the values of sexuality and marriage traditionally held by the Javanese society. The scene suggests a liberal idea because based on Javanese societal norms sex is usually understood as an act of consummation within a legal and justified boundary that is marriage (Suseno 176; Malhotra 435, 437; Endraswara, Seksologi Jawa 106-107).

The sex scene presents the narrator and the cinematographer, Erik, half-naked on the bed. They act as if they are about to have sex. The scene rhetorically shows the endearment of the narrator to the cinematographer. It is vividly manifested as the narrator satirically addresses to the viewers saying, "To maintain the sexual intimacy between husband and wife, some married couple makes love here, after office hour or during lunch break, like me and my 'husband, Erik. Come, honey ..." Aesthetically, such representation employs some techniques. The camera movement is a steady rock with a high camera angle. The framing is a long shot capturing both the cinematographer and the narrator on the bed with an intimate gesture as if they were about to have sex. The mid-key lighting and deep focus shot are also employed. The scene ends with the diegetic sounds of the narrator and the cinematographer saying together, "We welcome you to Jakarta. Goodbye ..." The combination of these techniques produces both a realistic and dramatized image of the scene.

By performing the dramatized sex alluding to the free-sex phenomenon in Jakarta, the motel bedroom scene signifies that such a fictionalized sexual practice challenges the public moral view and the traditional marriage values held by the 
Javanese. The fictionality of the scene does not dilute the film's rhetorical message. As mentioned at the outset, Jamu argues that such a broad social belief, "We are a moralized society," needs questioning. Again, the scene does not reduce the film's rhetorical message. On the contrary, this fabricated action articulates that the film satirically and humorously plays with the idea of jamu, sex, existing moral and cultural values in Indonesia. With these all, Javaneseness represented precisely opposes the New Order's solemn and moralistic representation of the Javanese people.

The sexually driven quality of the scene is self-evident particularly when it is related to jamu, the traditional medicine. The filmmakers exploit jamu by connecting it with sex and prostitution as introduced by the narrator. It makes jamu a sort of symbol of irony to the moral view declared in the introductory scene of the film. This scene is aesthetically filmed using a hand-held camera movement with an eyelevel camera angle, a medium shot, natural lighting, and shallow focus. The scene presents the narrator near the national monument in Jakarta. The combination of these techniques emphasizes the importance of the narrator as the central figure in the scene. It goes along with the scene's introductory function to present the rhetorical claim of the narrator, based on the public moral view.

With such rhetorical declaration above, Jamu is understood as a documentary with a reconstructionist style illustrating a fabricated personal observation of the filmmakers. The film discloses the irony and ambivalence of the public moral view conveyed through the fictionality of the documentary by using recorded social realities. This personal observation leads the filmmakers to reveal the cultural practice of drinking jamu mixed with its aphrodisiac myth. The filmmakers visit the former prostitution area of Kramat Tunggak, the nightlife, and sex practices in Jakarta. This all suggests an attempt by the filmmakers to play with the public moral view.

The signification of the film is established from how jamu is introduced, investigated, and finally intersected with the free-sex dramatization of the motel bedroom scene. Such an arrangement evokes a perception as if traditional medicine is contributory to making sex practices (the free-sex phenomenon) widespread in Jakarta. With its myth of aphrodisiac content, traditional medicine seems to be illustrated as the entry point where virility and sex become significant issues in the film. The documentary has aesthetically communicated its satiric tone to the public moral view. The satiric tone is manifested from the way the narrator expresses it in the introductory scene. By the time she claims being in a moralized society, her facial expressions and hand gestures radiate some mockery of the public moral view. The narrator mockingly smiles as her right index finger is raised in front of 
her chest to make a denial gesture by moving the finger repeatedly. In other words, the narrator humorously doubts the public moral view.

The secretive quality of the Javaneseness that the film represents is also manifested in the motel bedroom scene. The scene humorously depicts a sex practice between the narrator and the cameraman. Besides undermining the public moral view, this fictionalized sex scene also articulates a mockery of the free-sex trend. The fictionalized free-sex is committed secretively under the pretext of maintaining the "husband and wife" sexual relationship in the motel bedroom scene. At this point, the scene demonstrates the film's comic ridicule of a fictionalized adultery, the free-sex phenomenon in Jakarta. The reasons for distance, fatigue, and maintaining the "husband and wife" sexual relations are made up to satirize such a secretive sex practice trend. The ways the narrator and the cinematographer perform sex in the motel bedroom as described previously convey their satire and mock of the imagined phenomenon. Before the consummation between "husband and wife" is imagined to proceed, the cinematographer, Erik, appears on the screen. He takes off his T-shirt and jeans. Then, the scene highlights his underpants reading "Jangan lupa pakai kondom [Don't forget to wear condom]" on the back of the underpants. This comic ridicule amplifies the satiric tone of the film. By showing this fictionalized secretive act of adultery in the motel bedroom, the abstract ideal of New Order's Javaneseness is jocularly contested.

\section{Obedient and yet Adherent Javanese}

Kulo Ndiko Sami is a documentary film with a combination of sociopolitical and cultural issues. It tells the cultural struggle of the Sikep communities to obtain the government's acknowledgment of their traditional faith on the Sikep's identity card. They fail to get it. This enables the film to communicate the theme of identity. Kulo Ndiko Sami whose sociopolitical dimension is strongly vivid cannot be comprehensively understood without correlating it with the cultural stigma used to be attributed to the Sikep.

The New Order regime had stigmatized the Sikep people as "backward" and "abnormal" peasantry from the mainstream Javanese. Therefore, the Sikep were encouraged and repressed to "leave their Samin teachings and be normal" (Widodo 261). The New Order's stigma to the Sikep for being "backward" and "abnormal" Javanese is definitely against the regime's ideal construct of the Javanese who is refined in language, moralistic in behavior, developmental and capitalistic in attitude and orientation. 
This kind of stigmatization was inherited from the Dutch colonial government's view. The view was based on the assessment conducted by Jasper. Jasper was the assistant resident of Tuban who regarded the Sikep as a group of Javanese with "mental deviance." Jasper's report concluded that the Sikep with their traditional faith, the Religion of Adam, appeared as the result of an enormous social change in Java. The cultivation system of the Dutch Ethical Policy imposed from the end of the nineteenth century to the dawn of the twentieth century rendered a great social transformation. The policy imposed by the colonial government had impacted the way of life of some traditional peasants who used to be independent (Widodo 267). Because these independent traditional peasants denied the cultivation and the corvée (unpaid labor peasants) system, they launched their resistance to the colonial government and the Javanese aristocrats. This marked the birth of the Sikep communities. They were adamant. They created their belief system (Religion of Adam), refused to pay tax, disobeyed village communal duties, and spoke to the aristocrats with the Javanese common language (ngoko) instead of the refined one (kromo) as commonly practiced (Korver 250; King, "Some Observations" 459$460)$. Consequently, they are considered "the other" by the mainstream Javanese (Widodo 272).

Unlike the New Order's and the Dutch colonial government's stigma to the Sikep, Kulo Ndiko Sami portrays the Sikep as a marginalized Javanese who is obedient to the government's law and yet determined to preserve their faith and tradition. Representing a marginalized group of the Javanese appearing to be obedient before the law and the government apparatus but persistent in their principle and belief also does not suit the imagined community envisaged by the New Order regime. The sense of an imagined community generated by a collective awareness (comradeship) to be modern and progressive out of shared historicity and nationness wanted to be believed a la Anderson, which was also dreamed of by the New Order, does not apply here. The film represents the "inner domain" or the "spiritual domain" (Chatterjee, The Nation and Its Fragments 6; Chatterjee, "Whose Imagined Community?" 217) of the Sikep despite their failure to obtain the government's acknowledgment of their traditional faith. It bears the cultural identity of the Sikep. All testimonies of the Sikep depict their obedience to the government's law pertinent to possess an identity card. A case in point is the testimony of Turlan.

The interview scene shows Turlan holding his identity cards while giving the testimony. It is captured using the combination of eye level, low and high angle camera as well as close-up and extreme close-up shots. He strongly wishes that his Sikep's belief will be officially imprinted on his identity card, or that it will be just left unstated. When Turlan receives his identity card, it is not as he expects. He finds out that Buddhism is imprinted on his identity card as his religion. The film shows a close-up shot of his identity cards. The cards are put on a table in 
an upward position exposing the data of his old and new identity cards. The old card shows that his religion is Islam, but the new card is Buddhism. Thus, none of Turlan's identity cards expresses his Religion of Adam. It proves that what Turlan wished is not accommodated by the system.

The interview scene with Turlan was interspersed with a shot of a computer screen and a civil servant working on the computer in the district office. This shot, using a fly-on-the-wall technique, depicts a moment when Gunritno, a Sikep and the film's narrator, asked the civil servant to clarify the reason why the Sikep's traditional faith could not be expressed on their identity cards. Feeling annoyed by the question, the civil servant shared with Gunritno the experience he had with Turlan. The civil servant told Gunritno that he had asked Turlan to input Turlan's data on the computer by himself. Such was the response of the civil servant to refute Turlan's assumption that there was a manipulation in the process. The civil servant argued that things had been automatically set in the computer program. Then, the framing returns to the interview scene of Turlan where Turlan holds his identity cards in a close-up shot. From close-up framing, the cards are zoomed out at a high angle and over the shoulder camera. This all signifies the acceptance of the Sikep to the situation, the indicated manipulation of the official process to apply for an identity card.

Although Kulo Ndiko Sami describes the Sikep as obedient Javanese, the documentary also represents the Sikep's strong adherence to their traditional faith and principles. The film shows this in a series of scenes. The scenes demonstrate how Sikep people strive to find a solution to the problem they encounter. These scenes show Gunritno and his family members, yearns for Sikep's aspiration to the district, regional government offices, and legislature. The scenes, which are recorded using the fly-on-the-wall technique, capture the struggle of Gunritno's band to communicate what all Sikep plead for. They wish that the Indonesian government officially recognized their traditional faith. However, their attempt, as the scenes demonstrate, fail. This failure and the refutation of the officials portray the Sikep as the marginalized Javanese sub-ethnic group. The documentary also delineates an image of the Sikep community that is determined in their struggle. This marginalized and yet determined image of the Sikep community provides a different representation of Javaneseness than that of the aristocratic image of being Javanese by the New Order. In this respect, the film expresses a more democratized and personal representation of Javaneseness.

The scene begins with Gunritno and his band heading for the district office of Sukolilo, Pati. There they meet the head of the district, Sutriyono, to clarify the reason why Sikep's traditional belief cannot be expressed on their identity cards. Sutriyono accompanied by his staff carefully explains the situation regarding the 
process of applying for an identity card to the Sikep. Sutriyono argues that as the head of the district he cannot fulfill Sikep's aspiration. The Indonesian government, according to Sutriyono's understanding of the law, only acknowledges five religions: Islam, Protestantism, Catholicism, Hinduism, and Buddhism. Therefore, Sutriyono admits that he always instructs his subordinates to categorize the applicants' religions based on the five religions above. As Sutriyono explains this, the scene shows him at the center of the frame in a low angle shot, heightening a sense of unquestioned authority and centrality he has over the Sikep.

Gunritno, as the speaker of his band, keeps on persuading Sutriyono to find a solution to the problem. Gunritno, also captured at a low angle, offers an alternative, asking if it is possible for the government to leave the Sikep's religion unstated on their identity cards. Sutriyono refuses the idea, as he is persistent that each citizen's religion, by law, must be stated and imprinted on the identity card. The camera angle shifts to eye-level as Sutriyono advises the Sikep to go to the regional registrar's office of Pati if the Sikep is determined with their wish. The change in camera angle seems to help the change of mood of Sutriyono from being firm to being slightly soft. Gunritno and his band, then, go to the registrar's office as suggested.

The scene portraying Gunritno and his band in the registrar's office starts with the Sikep getting off their motorcycles. They go inside the office. Gunritno looks for someone in some rooms. He looks confused, as he finds no one to ask. Then, he asks some civil servants for an opportunity to meet the head of the registrar's office. They lead Gunritno to the room of the head of the office. There, what happens between Gunritno and the officials is not captured because the filmmaker is not allowed to record their meeting. As the closed meeting is taking place, the scene in close-up and medium shots shows Gunritno's family members patiently waiting for Gunritno to come out. The scene, in a medium shot and eye-level angle, also captures some civil servants showing their disgruntled expressions with the unexpected visit of the Sikep and the filmmaker. Again, this scene also demonstrates how the Sikep community is stereotyped and marginalized as indicated by the treatment of the civil servants. The scene implies that problems concerning the Sikep community need to be handled off-the-record.

As Gunritno appears, the scene in the tracking shot follows the Sikep's departure to the legislative body of Pati. Having arrived in the office, a legislature member receives Gunritno's band. Unlike what happened in the district and the registrar offices, the atmosphere of their meeting here is more light-hearted. The scene shows how the legislative member politely and warmly explains that the application program of the identity card is set and determined by the central government in Jakarta. The legislature member argues that the regional administrators only follow 
what has been programmed via a computerized system by the central government. He reaffirms that the government of Indonesia in the meantime officially recognizes five religions only.

About this, the legislature member cannot do anything to assist the Sikep. He will bring the Sikep's issue to the regional legislative assembly. He seems to give a hope that the assembly may further discuss the Sikep's wish to the House of Representatives at the national level. During the meeting, the scene in the eye-level angle and medium shots shows the legislature holding a cigar while explaining to Gunritno and his band. Gunritno and his wife are also filmed at an eye-level angle and medium shot. An over-the-shoulder shot capturing a drama-like program on television intercepts this scene. The shot presents two men where one of them makes a hand gesture, begging the other man. The result of the meeting with the legislature member remains fruitless.

All of these scenes convey the Sikep's determination to materialize their wish, the government's acknowledgment of their religion. This marginalized, obedient, and yet determined image of the Sikep community is different from the image of calm, well-mannered, and aristocratic Javanese idealized by the New Order. The Sikep does not hesitate to meet and ask anyone whom he or she thinks capable of assisting and solving the situation. Without any prior agreement, they seek an audience with the officials from the district to the regional levels. They finally realize that the officials cannot provide a solution to the problem that they do not initially incur. They stand to keep on struggling for their religious recognition remains.

The cultural struggle of the Sikep philosophically reflects some principles that have characterized Sikep's way of life. This may sound nativist or provincial, and yet they are honest about what they consider important to human values. These principles are rooted in their traditional belief (Benda and Castles 227-228; King, "Some Observations" 473-474; Korver 250; Sulistiono 42). From their Religion of Adam, the principles of benevolence, patience, honesty, and non-violence are strictly adhered to and implemented in their two main orders: establishing family life through marriage and living as farmers (Shiraishi 113-114; Ba'asyin and Ba'asyin 13-15, 157-158). The Sikep never yields these two orders and principles as the film demonstrates. All witnesses of the Sikep and their environments are of the farming world. The complication of gaining an identity card encountered by the Sikep comes along with the film's rhetorical message of the government's recognition of cultural and religious diversity. Kulo Ndiko Sami tacitly addresses this issue. The film questions the government's commitment to protect and respect cultural and religious diversity. Kulo Ndiko Sami demonstrates a representation of Javanese people (the Sikep) that is not as what historically, politically, and culturally stigmatized for being "backward" and "abnormal" by the New Order. The film does 
not represent them for being refined, modern, and progressive. They have their belief and tradition that need to be recognized by the system.

\section{CONCLUSION}

The New Order regime once constructed an inchoate model of an imagined community or society of Indonesia (Indonesian-ness). To a certain extent, this imagined community $a$ la the New Order reflects a shared interest and need with that of Anderson's imagined community. It is the interest and the need for defining national identity, nationalism for the sake of progress and modernity.

The model envisaged by the regime was an imagined community that was educated, lofty in language, well-mannered, moralistic, and capitalistic. It was an absurd concept synthesizing some desired Javanese ethics and aristocratic traits aligned with other foreign concepts of morality, education, and capitalism. The result was the marriage of an oversimplified understanding of Javaneseness and desired ideals of the New Order.

Therefore, Javaneseness prevailed or desirable by the New Order was that of aristocratic orientation. Overtly, the construct was designed for the sake of development, progress, and modernity. Covertly, the construct politically helped the regime maintain the status quo, political stability. The construct politically legitimized the state to impose desirable policies, including that of the cultural one. As a result, the construct became the hegemonic narrative of the state.

Yet, in the first decade of the Reformasi era where thoughts and beliefs of the New Order still lingered, this hegemonic abstract of Javaneseness referring to an imagined community that was educated, lofty in language, well-mannered, moralistic, and capitalistic has been rivaled by more down-to-earth, subjective, and ephemeral projections of Javaneseness.

Javaneseness is not only court-centric and not defined by and within the power structure, or the state in the cases presented here. In the context of the Reformasi era, public participation has taken the role and shaped the interpretation. This suggests that there has been a shift from state to public interpretation operating in the documentary films studied. Any representation involving some elements of Javanese culture, however "incomplete" and "less" profound, to some degree can be still said to have partially illustrated Javaneseness but not claiming the single truth of Javaneseness. 
Jamu demonstrating the Javaneseness with the qualities of being liberal, sexually driven, and secretive is contradictory from the "handsome" notion of aristocratic, lofty in language, well-mannered, and moralistic Javanese and Indonesian as envisaged by the New Order. Similarly, this is also the case with Kulo Ndiko Sami. The film articulates Sedulur Sikep, the minority of the Javanese, who are obedient to the law, but adherent to their traditional values and faith despite all the social and cultural stigmatization they encountered. Javaneseness promoted by the New Order was intended to apply to the Sikep as well. Yet, they are persistent about who and what they are like. These two documentaries have intersected their different representations of Javaneseness with some "inner domain" (Chatterjee, "Whose Imagined Community?" 217) of Javanese cultural values. Jamu is intersected with the Javanese values of marriage and sex, while Kulo Ndiko Sami with the Religion of Adam.

The representations of Javaneseness of the documentaries prove to be beyond what is shown on the surface. Not only do the down-to-earth, subjective, and ephemeral images here construct alternative views of Javaneseness, but it also expresses the idea that Javaneseness cannot be confined within a single interpretation but through differences. To a certain degree, understanding Javaneseness through its variety of differences enables people to think that Javanese people and their cultural expressions bearing a cultural entity called Javaneseness are never uniform. Javaneseness is fluid and therefore subject to multi-interpretations, and will possibly be contextually redefined and remodified throughout history. Javaneseness may be one in word, but many in meanings. So, these representations are the counter-imaginary of that of the New Order.

Towards a more egalitarian culture and society of Indonesia, the so-called counter imaginaries need not be necessarily comprehended as a threat to the unity of the nation. The Indonesian nation-building is not immune from what Anderson has theorized (Imagined Communities 6) as well as what Chatterjee has questioned ("Whose Imagined Community?" 216-217). The fact also points out the modern nation of Indonesia was born out of centuries of the anti-colonial struggle by hundreds of ethnic groups living in Nusantara in the intersection of world history (colonialism and both world wars). Processes of assimilation and acculturation have taken place naturally through peoples' mobility within the country and abroad.

The remaining question is whether or not ethnic identity still matters in contemporary Indonesia. It still matters, not in the sense of defining and demonstrating ethnicity exclusively but inclusively. The reason is due to the idea that culture is "nurtured" (constructed) and not "nature." Precisely because it is nurtured, then considerations of where, when, by whom, and how an individual cultivates himself or herself within one's physical, emotional, cultural, and 
geographical limits or balance do matter. This will be the case especially when one is trying to be sincere to himself and herself, while at the same time learning to be open-minded to constant changes or adaptations from outside his or her boundaries. It is particularly needed for the multicultural societies of Indonesia. Counter-imaginaries let people come to an awareness that there is something that needs understanding and communicating in sociocultural (inter-ethnic) relations. How Javanese understand themselves and be understood by others is part of nation-building. Then, when such understanding is achieved, it could propel them to giving a positive contribution to the greater society of Indonesia and perhaps beyond. Any inter-ethnic conflicts in Indonesia have, at great cost, taught people that it is not ethnicity that has become the source of the conflicts, but other aspects, usually related to political and economic interests (Chatterjee, "Whose Imagined Community?" 217). 


\section{Notes}

1. Ayu Utami's famous novels are Saman (1998), Larung (200o), Lalita (2012), and Maya (2013).

2. In-Docs is an Indonesian-based non-profit institution committed to cultivate a culture of openness through documentary films (In-Docs)

3. Ford Foundation is a global private foundation advancing human welfare and cultures. The foundation is headquartered in New York (Ford Foundation)

4. Anderson also observed the regimes and context in Indonesia as one of his points of departure in theorizing his premise.

5. Before 1820, the Dutch through its state-sponsored company, Dutch East Indies Company/VOC had already colonized Nusantara (present-day Indonesia) since 1619 (Vickers 10). 


\section{Works Cited}

Anderson, Benedict. "Bung Karno and the Fossilization of Soekarno's Thought." Indonesia, vol. 74, no. 184, 2002, pp. 1-19.

--. Imagined Communities: Reflections on the Origin and Spread of Nationalism. Revised ed., Verso, 2006.

Arifianto, Budi Dwi, and Fajar Junaedi. "Distribusi Dan Eksibisi Film Alternatif Di Yogyakarta, Resistensi Atas Praktek Dominasi Film Di Indonesia." Jurnal ASPIKOM, vol. 2, no. 2, 2014, p. 74, doi:10.24329/aspikom.v2i2.61.

Ba'asyin, Anis Sholeh, and Muhammad Anis Ba'asyin. Samin : Mistisisme Petani Di Tengah Pergolakan. Gigih Pustaka Mandiri, 2014.

Balink, Albert. De Merapo Dreight (Mount Merapi Looms). Java Pacific Film, 1934.

Barnouw, Erik. Documentary: A History of the Non-Fiction Film. 2nd ed., Oxford UP, 1993.

Basuki, Ribut. "Panakawan's Discourse of Power in Javanese Shadow Puppet during the New Order Regime: From Traditional Perspective to New Historicism.” K@ta, vol. 8, no. 1, 2006, pp. 68-88, doi:https://doi.org/10.9744/kata.8.1.68-88.

Beers, Susan Jane. Jamu: The Ancient Indonesian Art of Herbal Healing. Periplus, 2001.

Benda, Harry, and Lance Castles. "The Samin Movement." Bijdragen Tot de Taal-, LandEn Volkenkunde, vol. 125, no. 2, 1969, pp. 207-240, http://www.kitlv-journals.nl.

Bernard, Sheila Curran. Documentary Storytelling: Making Stronger and More Dramatic Nonfiction Films. Focal, 2007.

Bordwell, David, and Kristin Thompson. 2013. Film Art: An Introduction. 1oth ed., McGraw-Hill, 2013.

Bruzzi, Stella. New Documentary: A Critical Introduction. Routledge, 2006.

Budianta, Melani. "Discourse of Cultural Identity in Indonesia During the 1997-1998 Monetary Crisis." Inter-Asia Cultural Studies, vol. 1, no. 1, 200o, pp. 109-128, doi:10.1080/146493700361033.

Chatterjee, Partha. The Nation and Its Fragments: Colonial and Postcolonial Histories. Princeton UP, 1993, doi:10.2307/2168288.

-.- "Whose Imagined Community?" Mapping the Nation, edited by Gopal Balakrishnan, Verso, 2012, pp. 214-25, doi:10.4324/9781315790343-4.

Cohen, Matthew I. "Wayang Kulit Tradisional Dan Pasca-Tradisional Di Jawa Masa Kini." Kajian Seni, vol. 1, no. 1, 2014, pp. 1-18, doi:https://doi.org/10.22146/art.5965.

Elfahmi, et al. "Jamu: Indonesian Traditional Herbal Medicine towards Rational Phytopharmacological Use." Journal of Herbal Medicine, vol. 4, no. 2, 2014, pp. 51-73, Elsevier, doi:10.1016/j.hermed.2014.01.002.

Endraswara, Suwardi. Falsafah Kepemimpinan Jawa. Narasi, 2013.

-.. Memayu Hayuning Bawana. Narasi, 2013.

-. Seksologi Jawa. Wedatama Widya Sastra, 2013.

Errington, Joseph. "Self and Self-Conduct among the Javanese Priyayi Elite." American Ethnologist, vol. 11, no. 2, 1984, pp. 275-290, doi:10.1525/ae.1984.11.2.02aooo40. 
FFD. "10 Finalis Kompetisi Film Dokumenter FFD 2005 Kategori Profesional." Festival Film Dokumenter 2005 Program Book, FFD, 2005, pp. 1-16, https://issuu.com/ffdjogja/docs/ katalog_2005.

Ford Foundation. "About Us." Ford Foundation, 2017, https://www.fordfoundation.org/ about-us/.

Foulcher, Keith. "The Construction of an Indonesian National Culture: Patterns of Hegemony and Resistance." State and Civil Society in Indonesia., edited by Arief Budiman, Centre of Southeast Asian Studies, Monash U, 1990, pp. 302-320.

Francoeur, Robert T., and Raymond J. Noonan, editors. The Continuum Complete International Encyclopedia of Sexuality. Continuum, 2004.

Franken, Mannus. Tanah Sabrang (Het Land Aan De Overkant). Anifilm, 1938, https://www.eyefilm.nl/en/collection/film-history/film/ tanah-sabrang-het-land-aan-de-overkant.

GATRA. "Kejutan Jamu Ayu." Apa Dan Siapa, 2002, http://arsip.gatra.com/2002-12-03/ artikel.php?id=22468.

Gunritno, et al. Kulo Ndiko Sami. In-Docs and Ford Foundation, 2005.

Hanan, David. "Innovation and Tradition in Indonesian Cinema." Third Text, vol. 24, no. 1, 2010, pp. 107-121, doi:10.1080/09528820903488984.

--. "Observational Documentary Comes to Indonesia: Aryo Danusiri's Lukas' Moment." Southeast Asian Independent Cinema, edited by Baumgartel Tilman, Hong Kong UP, 2012, http://www.jstor.org/stable/j.ctt1xwgkr.

-.. "The Films of Garin Nugroho: Political Documentaries and Essay Films by Garin Nugroho in Late New Order and Post Reformasi Indonesia." Spectator, vol. 42, no. 2, 2004, pp. 39-49.

Hartiningsih, Maria. "Persona: Jangan Meratapi Seni Tradisi." KOMPAS, Jan. 20o8, p. 12, www.kompasdata.id/Search/NewsDetail/16646547.

Hatley, Ron, et al. Other Javas Away from the Kraton. Monash U, 1984.

Heeren, Katinka van. Contemporary Indonesian Film: Spirits of Reform and Ghosts from the Past. KITLV, 2012.

Heider, Karl G. Indonesian Cinema: National Culture on Screen. U of Hawaii P, 1991.

Herusatoto, Budiono. Simbolisme Dalam Budaya Jawa. Hanindita, 2000.

Heryanto, Ariel. Identitas Dan Kenikmatan: Politik Budaya Layar Indonesia. Kepustakaan Populer Gramedia, 2015.

--. Popular Culture in Indonesia: Fluid Identities in Post-Authoritarian Politics. Routledge, 2008.

Howell, Julia D. "Sufism and the Indonesian Islamic Revival." The Journal of Asian Studies, vol. 6o, no. 3, 2001, pp. 701-729, http://www.jstor.org/stable/2700107.

Hughes-Freeland, Felicia. "Women's Creativity in Indonesian Cinema 39(115), 417-444." Indonesia and the Malay World, vol. 39, no. 115, 2011, pp. 417-444, doi:10.1080/1363981 1.2011.614089.

Hunter, Helen-Louise. Sukarno and the Indonesian Coup: The Untold Story. Praeger Security International, 2007. 
IdFilmCenter. "Jamu." Indonesian Film Center, 2012, https://www.indonesianfilmcenter. com/watchfilms/index/search/o/o/Jamu.

Imanjaya, Ekky. The Other Side of Indonesia: New Order's Indonesian Exploitation Cinema as Cult Films. 18, 2009, www.colloquy.monash.edu.au/issue18/imanjaya.pdf. Accessed 10 Jan. 2015.

In-Docs. About In-Docs. 2015, https://in-docs.org/about/?lang=id.

Irawanto, Budi. "Beyond Dramatic Moments: Indonesian Documentary Films in the 21st Century." DocNet Southeast Asia, 2017, http://www.goethe.de/ins/id/lp/prj/dns/dfm/ ind/enindex.htm.

Isla, Veronica L. "Challenging Grand Narratives on the Nation: ASEAN Independent Filmmakers' Indirect Participation in Development Discourse." Inter-Asia Cultural Studies, vol. 11, no. 3, 2010, pp. 457-469, doi:10.1080/14649373.2010.484208.

Jones, Tod. Culture, Power, and Authoritarianism in the Indonesian State: Cultural Policy across the Twentieth-Century to the Reform Era. Brill-KITLV, 2013, https://brill.com/ view/title/24266.

--. "Indonesian Cultural Policy in the Reform Era." Indonesia, no. 93, 2012, pp. 147-176, http://muse.jhu.edu/journals/ind/summary/vo93/93.jones.htm.

Karnanta, Kukuh Y. "Ekonomi Politik Film Dokumenter Indonesia: Dependensi Industri Film Dokumenter Indonesia Kepada Lembaga Donor Asing." Lakon: Jurnal Kajian Sastra Dan Budaya, vol. 1, no. 1, 2012, pp. 1-11, doi:http://dx.doi.org/10.20473/lakon. vii1.1908.

King, Victor. T. "Status, Economic Determinism and Monocausality: More on the Samin." Bijdragen Tot de Taal-, Land-En Volkenkunde, vol. 133, no. 2, 1977, pp. 350-354, http:// www.kitlv-journals.nl.

King, Victor T. "Some Observations on the Samin Movement of North-Central Java. Suggestions for the Theoretical Analysis of the Dynamics of Rural Unrest." Bijdragen Tot de Taal-, Land-En Volkenkunde, vol. 129, no. 4, 1973, pp. 457-481, https://www.jstor. org/stable/27861364.

Klinken, Garry van. Communal Violence and Democratization in Indonesia: Small Town Wars. Routledge, 2007.

Komite Nasional. Gelora. Komite Nasional, 1945.

Korver, A. Pieter E. "The Samin Movement and Millenarism." Bijdragen Tot de Taal-, LandEn Volkenkunde, vol. 132, no. 2/3, 1976, pp. 249-266, http://www.kitlv-journals.nl.

Kwok, Yenni. “The Dark Side of Freedom: Troubling Focus on Indonesia's Have-Nots." Asiaweek, 200o, http://edition.cnn.com/ASIANOW/asiaweek/97/0307/feat1.html.

Laksono, Paschalis Maria. Tradition in Javanese Social Structure: Kingdom and Countryside: Changes in the Javanese Conceptual Model. Gadjah Mada UP, 1990.

Mae, Indra J. "Sejarah Film Dokumenter Di Indonesia." Kabarkami, 2014, http://www. kabarkami.com/sejarah-film-dokumenter-di-indonesia.html.

Malhotra, Anju. "Gender and the Timing of Marriage: Rural-Urban Differences in Java." Journal of Marriage and Family, vol. 59, no. 2, 1997, pp. 430-450, doi:10.2307/353481. 
Michalik, Yvonne. "Indonesian Women Filmmakers: Creating a New Female Identity?" Indonesia and the Malay World, vol. 43, no. 127, 2015, pp. 378-396, doi:10.108o/1363981 1.2015.1054139.

Mietzner, Marcus. Reinventing Asian Populism: Jokowi's Rise, Democracy, and Political Contestation in Indonesia, edited by Dieter Ernst and Marcus Mietzner, The East-West Center, 2015.

Monnikendam, Vincent. Moeder Dao, De Schildpadgelijkende (Mother Dao, the Turtlelike). Nederlandse Programma Stichting (NPS) and Les Films du Paradoxe, 1933.

Mulder, Niels. "Aliran Kebatinan as an Expression of the Javanese Worldview." Journal of Southeast Asian Studies, vol. 1, no. 1, 1970, pp. 105-114, http://www.jstor.org/ stable/20069876.

--. Mysticism and Everyday Life in Contemporary Java: Cultural Persistence and Change, Singapore UP, 1983.

-. Mysticism in Java : Ideology in Indonesia. Penerbit Kanisius, 2005.

Nichols, Bill. Introduction to Documentary. 2nd ed., Indiana UP, 2010.

Nihon Eiga Sha. Berdjoang (Hope of the South). Nihon Eiga Sha, 1944, http://www.yidff. jp/97/cat111/97c123-e.html.

--. Call for Romusha. Nihon Eiga Sha, 1944, http://www.yidff.jp/97/cat111/97c123-e.html.

--. The Celebration of the Emperor's Birthday and the Re-Opening of the Medical School for the Natives. Nihon Eiga Sha, 1943, http://www.yidff.jp/97/cat111/97c123-e.html.

-.. Volunteer for the Army. Nihon Eiga Sha, 1943, http://www.yidff.jp/97/cat111/97c123-e. html.

Nugroho, Garin. Daun Di Atas Bantal (Leaf on a Pillow). PT Christine Hakim Film, 1997.

--. Dongeng Kancil Tentang Kemerdekaan (Kancil's Tale of Independence). SET Film and NHK Japan, 1995.

Nugroho, Garin, and Dyna Herlina Suwarto. Krisis Dan Paradoks Film Indonesia. PT Kompas Media Nusantara, 2015.

Parlindungan, Utan. "Mitos Genjer-Genjer: Politik Makna Dalam Lagu. 2016, 17(3), 18." JSP Jurnal Ilmu Sosial Dan Ilmu Politik, vol. 17, no. 3, 2016, pp. 236-253, doi:10.22146/ jsp.13083.

Pemberton, John. On the Subject of Java. Cornell UP, 1994.

Putri, Idola P. "Mendefinisikan Ulang Film Indie : Deskripsi Perkembangan Sinema Independen Indonesia." Jurnal Komunikasi Indonesia, vol. 2, no. 2, 2013, pp. 119-128, http://download.portalgaruda.org/article.php?article $=525634 \& v a l=10745 \&$ title=Mendef inisikan Ulang Film Indie: Deskripsi Perkembangan Sinema Independen Indonesia.

Ratna, Lulu. "Indonesian Short Films after Reformasi 1998." Inter-Asia Cultural Studies, vol. 8, no. 2, 2007, pp. 304-307, doi:10.1080/14649370701238805.

Robertson-Snape, Fiona. "Corruption, Collusion, and Nepotism in Indonesia." Third World Quarterly, vol. 20, no. 3, 1999, pp. 589-602, doi:10.1080/01436599913703.

Rosalia, Indra. "Film Independen, Fondasi Industri Perfilman Indonesia. Pdf." Beritagar.Id., 2016, pp. 1-14, https://beritagar.id/artikel/laporan-khas/ film-independen-fondasi-industri-perfilman-indonesia.

Sen, Krishna. Indonesian Cinema: Framing the New Order. Zed Books, 1994. 
Sen, Krishna, and David T. Hill. Media, Culture, and Politics in Indonesia. Equinox Pub., 2007.

Shiraishi, Takashi. "Dangir's Testimony: Saminism Reconsidered." Indonesia, no. 50, 1990, pp. 95-120, http://www.jstor.org/stable/3351232.

Soedarsono, Riswan, and Harini S. Roemantyo. "Jamu as Traditional Medicine in Java." South Pacific Study, vol. 23, no. 1, 2002, pp. 1-10, http://cpi.kagoshima-u.ac.jp/ publications/southpacificstudies/archivespst.html\#SPS.

Sulistiono, Singgih T. "Saministo Phobia." CITRA LEKHA, vol. 16, no. 2, 2011, pp. 31-44, http://download.portalgaruda.org/article.php?article $=80863 \&$ val $=1311$.

Suseno, Frans-Magnis. Etika Jawa : Sebuah Analisa Falsafi Tentang Kebijaksanaan Hidup Jawa. Gramedia, 1996.

Sutherland, Heather. "The Priyayi." Indonesia, no. 19, Apr. 1975, pp. 57-77, doi:10.2307/3350702.

Uhde, Jan. "Indonesian Director Garin Nugroho in Conversation with Kinema." KINEMA-University of Waterloo, 1999, http://www.kinema.uwaterloo.ca/article. php?KINEMAid=208\&feature.

Utami, Ayu, and Erik Prasetya. Jamu Jakarta. Ayu Utami Production, 2002.

Vatikiotis, Michael. Indonesian Politics Under Suharto: The Rise and Fall of the New Order. Routledge, 2003.

Vickers, Adrian. A History of Modern Indonesia. Cambridge, 2005.

Werdiningsih, Yuli Kurniati. "Harmonisasi Hubungan Tuhan Dengan Manusia Dalam Serat Sastra Gendhing, Pembacaan Hermeneutik Terhadap Sastra Jawa Transendental.” Seminar Nasional: Sastra, Pendidikan Karaketer Dan Industri Kreatif, edited by Miftakhul Huda, Universitas Muhammadiyah Surakarta, 2015, pp. 314-320, https:// publikasiilmiah.ums.ac.id/handle/11617/5610.

Widodo, Amrih. "Samin in the New Order: The Politics of Encounter and Isolation." Imagining Indonesia: Cultural Politics and Political Culture, edited by Jim Schiller and Barbara Martin-Schiller, Ohio U Center for International Studies, 1997, pp. 261-287.

Woodward, Mark. Java, Indonesia, and Islam. Springer, 2011.

YIDFF Organizing Committee. "Indonesia under Japanese Military Rule." Yamagata International Documentary Film Festival, 1997, http://www.yidff.jp/97/cat111/97c123-e. html. 